\title{
Differential Distribution of Glycine Receptor Subtypes at the Rat Calyx of Held Synapse
}

\author{
Bohdana Hruskova, ${ }^{1 \star}$ Johana Trojanova, ${ }^{1,2 \star}$ Akos Kulik, ${ }^{2,4,5}$ Michaela Kralikova, ${ }^{1}$ Kateryna Pysanenko, ${ }^{1}$ Zbynek Bures, ${ }^{1}$ \\ Josef Syka, ${ }^{1}$ Laurence 0. Trussell, ${ }^{3}$ and Rostislav Turecek ${ }^{1}$ \\ ${ }^{1}$ Department of Auditory Neuroscience, Institute of Experimental Medicine ASCR, 14220 Prague, Czech Republic; ${ }^{2}$ Institute of Anatomy and Cell Biology, \\ Department of Neuroanatomy, University of Freiburg, D-79104 Freiburg, Germany; ${ }^{3}$ Oregon Hearing Research Center and Vollum Institute, Oregon Health \\ and Science University, Portland, Oregon 97239; and ${ }^{4}$ Department of Physiology II and ${ }^{5}$ BIOSS Centre for Biological Signalling Studies, University of \\ Freiburg, D-79104 Freiburg, Germany
}

The properties of glycine receptors (GlyRs) depend upon their subunit composition. While the prevalent adult forms of GlyRs are heteromers, previous reports suggested functional $\alpha$ homomeric receptors in mature nervous tissues. Here we show two functionally different GlyRs populations in the rat medial nucleus of trapezoid body (MNTB). Postsynaptic receptors formed $\alpha 1 / \beta$-containing clusters on somatodendritic domains of MNTB principal neurons, colocalizing with glycinergic nerve endings to mediate fast, phasic IPSCs. In contrast, presynaptic receptors on glutamatergic calyx of Held terminals were composed of dispersed, homomeric $\alpha 1$ receptors. Interestingly, the parent cell bodies of the calyces of Held, the globular bushy cells of the cochlear nucleus, expressed somatodendritic receptors ( $\alpha 1 / \beta$ heteromers) and showed similar clustering and pharmacological profile as GlyRs on MNTB principal cells. These results suggest that specific targeting of GlyR $\beta$-subunit produces segregation of GlyR subtypes involved in two different mechanisms of modulation of synaptic strength.

\section{Introduction}

Heterogeneity of receptor subtypes dramatically enhances the capacity of synapses to transmit complex signals. The diversity of receptors in the CNS is generated in several ways, including expression of multiple genes encoding different forms of receptor subunit or alternative splicing during transcription (Schofield et al., 1990). GABA and glycine, the main inhibitory transmitters in the CNS, mediate their effects through the Cys-loop family of ionotropic receptors, and are characterized by a diversity of subunits (Lynch, 2004). Glycine receptors (GlyRs) are pentamers formed by $\alpha 1-4$ and $\beta$-subunits and their splice variants; properties of GlyR-ion channel complexes are strongly influenced by their subunit composition (Laube et al., 2002; Lynch, 2004; Webb and Lynch, 2007; Legendre et al., 2009). Individual receptor subtypes show differential regional distribution and developmental expression in the CNS. GlyRs formed as heteromers of two $\alpha$-subunits and three $\beta$-subunits cluster at postsynaptic sites due to interactions between the $\beta$-subunit and gephyrin (Kneussel and Betz, 2000a; Grudzinska et al., 2005), and likely represent

\footnotetext{
Received March 29, 2012; revised Sept. 6, 2012; accepted 0ct. 4, 2012.

Author contributions: J.T., A.K., J.S., and R.T. designed research; B.H., J.T., A.K., M.K., K.P., and R.T. performed research; B.H., J.T., A.K., M.K., Z.B., and R.T. analyzed data; L.O.T. and R.T. wrote the paper.

This study was supported by grants from the Grant Agency of the Czech Republic (P303/11/0131), the Wellcome Trust (WT073966), the National Institutes of Health (DC004450 to L.0.T.), and Deutsche Forschungsgemeinschaft (SFB 780 A2). We thank Heinz Wassle for valuable advice at an initial stage of this project, and Dieter Langosch for kind gift of cyanotriphenylborate.

*B.H. and J.T. contributed equally to this work.

Correspondence should be addressed to Rostislav Turecek, Department of Auditory Neuroscience, Institute of Experimental Medicine ASCR, Videnska 1083, 14220 Prague Czech Republic. E-mail: turecek@biomed.cas.cz.

DOI:10.1523/JNEUROSCI.1547-12.2012

Copyright $\odot 2012$ the authors $\quad 0270-6474 / 12 / 3217012-13 \$ 15.00 / 0$
}

most of the GlyRs in the adult CNS (Lynch, 2009). In the absence of $\beta$-subunit, $\alpha$-subunits can still form functional GlyRs (Betz and Laube, 2006), as shown in embryonic neurons (Flint et al., 1998). There is, however, only sparse evidence for the existence of $\alpha$-homomeric receptors in the mature mammalian CNS (Deleuze et al., 2005). Moreover, the segregated distribution of homomeric and heteromeric GlyRs into cellular compartments of neurons still awaits confirmation (Lynch, 2009).

Glycinergic transmission plays an essential role in the superior olivary complex (SOC) of the auditory brainstem. The nuclei of the SOC use glycine-mediated signals for encoding interaural intensity differences that form a basis for sound source localization (Kandler and Gillespie, 2005; Grothe et al., 2010). Glycinergic principal neurons of the medial nucleus of trapezoid body (MNTB) represent a critical component of the SOC. They receive giant glutamatergic axon terminals (calyces of Held) from globular bushy cells (GBCs) located in the contralateral cochlear nucleus and convert the excitatory signals to inhibitory signals directed to other SOC nuclei (Oertel, 1999; Schneggenburger and Forsythe, 2006). The calyx of Held synapse thus works as a relay suited to providing reliable inhibitory signals (Borst and Soria van Hoeve, 2012). Interestingly, the generation of those signals is itself subject to modulation by glycinergic transmission (KoppScheinpflug et al., 2011). Glycine released from inhibitory fibers exerts its effects in the MNTB via presynaptic and postsynaptic GlyRs. Presynaptic receptors mediate slow potentiation of glutamate released from the calyx while postsynaptic receptors mediate fast postsynaptic inhibition (Banks and Smith, 1992; Turecek and Trussell, 2001; Awatramani et al., 2004, 2005b; Price and Trussell, 2006). The differences in the kinetics suggest that gly- 
cine operates on two pharmacologically distinct receptor populations. Here, we show that physiological functions of presynaptic and postsynaptic GlyRs in the rat MNTB correlate with their subunit composition. We propose that the segregation of GlyR subtypes to presynaptic and postsynaptic compartments might reflect a common strategy for refining the capacity of glycine to modify excitation at synapses.

\section{Materials and Methods}

Slice preparation. For electrophysiology experiments, coronal or parasagittal brainstem slices were prepared from P12-P18 Wistar rats. Animals were decapitated in accordance with Animal Protection Law of the Czech Republic (compatible with European Community Council directives 86/ $609 / \mathrm{EEC}$ ). The brains were excised in ice-cold low $\mathrm{Ca}^{2+}$ artificial CSF (aCSF) containing the following (in $\mathrm{mM}$ ): $125 \mathrm{NaCl}, 2.5 \mathrm{KCl}, 2.5 \mathrm{MgCl}_{2}$, $0.1 \mathrm{CaCl}_{2}, 25$ glucose, $1.25 \mathrm{NaH}_{2} \mathrm{PO}_{4}, 25 \mathrm{NaHCO}_{2}, 0.5$ ascorbic acid, 3 myo-inositol, and 3 sodium pyruvate; gassed with $5 \% \mathrm{CO}_{2} / 95 \% \mathrm{O}_{2}$ to $\mathrm{pH}$ 7.3. Slices (250-280 $\mu \mathrm{m}$ thick) were cut in the low $\mathrm{Ca}^{2+}$ aCSF using a VT1200S vibratome (Leica), incubated at $37^{\circ} \mathrm{C}$ for $30 \mathrm{~min}$ and then stored at room temperature $\left(21-23^{\circ} \mathrm{C}\right)$ in a standard aCSF in which the concentrations of $\mathrm{MgCl}_{2}$ and $\mathrm{CaCl}_{2}$ were 1 and $2 \mathrm{~mm}$, respectively.

For light microscopy experiments, adult Wistar rats (P57-87, $n=48$ ) were deeply anesthetized with ketamine-xylazine $(100 \mathrm{mg} / \mathrm{kg}, 16 \mathrm{mg} / \mathrm{kg}$ body weight, i.p.) and perfused transcardially with $0.9 \%$ saline followed by $0.1 \mathrm{~m}$ phosphate buffer ( $\mathrm{PB}$; $\mathrm{pH} 7.4)$ containing $4 \%(\mathrm{w} / \mathrm{v})$ paraformaldehyde (PFA). After the perfusion, the brains were washed in PB several times and coronal or parasagittal slices of brainstem ( $300 \mu \mathrm{m}$ thick) were cut in $\mathrm{PB}$ and postfixed. The sections were then cryoprotected in graded sucrose solution $(10,20$, and $30 \mathrm{w} / \mathrm{v}$, respectively). Sections $(25 \mu \mathrm{m}$ thick) were cut by a cryostat CM 3050 S (Leica), mounted onto Superfrost slides, and stored at $-20^{\circ} \mathrm{C}$. For immunoelectron microscopy, deeply anesthetized adult male Wistar rats $(n=8)$ were perfused transcardially with $0.9 \%$ saline followed by fixative containing $4 \%$ (w/v) PFA, $15 \%$ (v/v) picric acid (saturated aqueous solution; $1.3 \%$ in $\mathrm{H}_{2} \mathrm{O}$ ), and $0.05 \%$ $(\mathrm{v} / \mathrm{v})$ glutaraldehyde in $0.1 \mathrm{M}$ PB. Brains were excised, washed in $\mathrm{PB}$, and 50 - $\mu \mathrm{m}$-thick coronal sections were cut using a VT1000S (Leica) tissue slicer. For in vitro retrograde axonal tracing, brainstem tissue blocks containing MNTB and anteroventral cochlear nucleus (AVCN) were cut in the low $\mathrm{Ca}^{2+}$ aCSF. Ten percent biotin dextran amine (BDA; 10,000 MW; Invitrogen) solution was pressure injected into the midline at the ventral side of brainstem (AVCN bushy cells labeling) or into the ipsilateral lateral superior olive nucleus (MNTB principal cells labeling) using a borosilicate glass micropipette (tip diameter 15-20 $\mu \mathrm{m}$ ). The latter allowed us to distinguish dendrites from axon in MNTB neurons. The blocks were then incubated in the $\mathrm{HCO}_{3}^{-}$-based aCSF for $6 \mathrm{~h}$ at room temperature, fixed with $4 \%(\mathrm{w} / \mathrm{v}) \mathrm{PFA}$ in $0.1 \mathrm{M} \mathrm{PB}$ at $4^{\circ} \mathrm{C}$ overnight.

Immunohistochemistry for light microscopy. Coronal or parasagittal sections were incubated overnight in PB containing 5\% (v/v) Chemiblocker (Millipore Bioscience Research Reagents), 1\% Triton X-100 (v/ v), $0.1 \% \mathrm{NaN}_{3}(\mathrm{w} / \mathrm{v})$, and primary antibodies. We used mouse primary antibodies raised against GlyR $\alpha 1$-subunit (mAb2b; dilution 1:1000, Synaptic Systems), gephyrin (mAb7a; 1:200, Synaptic Systems), and Rab3a (1:250; Synaptic Systems); rabbit primary antibodies anti-GlyR $\alpha 1$ (1:600; Synaptic Systems), anti-GlyR $\alpha 1 / \alpha 2$ (1:1000; Abcam), anti-GlyR $\alpha 2$ (1:150; Santa Cruz Biotechnology), anti-vesicular GABA transporter (1:500; Synaptic Systems), anti-calretinin (1:200; Invitrogen), anticalbindin D-28k (1:250; Swant), and goat anti-GlyR $\alpha 3$ (1:150; Santa Cruz Biotechnology). Slices were then washed and incubated for $2 \mathrm{~h}$ with secondary antibodies conjugated to either Alexa Fluor 488 (Invitrogen) or to CY3 (Jackson ImmunoResearch Laboratories). Slices labeled with BDA were incubated with streptavidin conjugated to Alexa Fluor 488. Coverslips were mounted with Aqua Poly/Mount (Polysciences). Incubation with primary antibodies was omitted for control slides. Images were taken using a confocal microscope Leica TSC-SP 1 and analyzed by Leica confocal software 2.5 or using Olympus FluoView FV-300 and analyzed by FluoView software.

Pre-embedding immunoelectron microscopy. Brainstem sections (50 $\mu \mathrm{m})$ were cryoprotected in a solution containing $25 \%(\mathrm{w} / \mathrm{v})$ sucrose and
$10 \%(\mathrm{v} / \mathrm{v})$ glycerol in $50 \mathrm{~mm}$ PB. The sections were freeze-thawed and incubated in a blocking solution containing $20 \%(\mathrm{v} / \mathrm{v})$ Chemiblocker in $50 \mathrm{~mm}$ Tris-buffered saline (TBS; pH 7.4) for $4 \mathrm{~h}$, followed by incubation with the primary antibodies diluted in TBS containing 5\% (v/v) Chemiblocker overnight at $4^{\circ} \mathrm{C}$. We used primary antibodies raised against GlyR $\alpha 1$ (mAb2b, 1:500; rabbit, 1:800), gephyrin (mAb7a; 1:200), and vesicular glutamate transporter 1 (vGluT1; guinea pig, 1:800; Synaptic Systems). The sections were then incubated with a mixture of biotinylated goat anti-guinea pig IgG antibody (Jackson ImmunoResearch Laboratories) and goat anti-rabbit IgG or goat anti-mouse IgG antibodies coupled to $1.4 \mathrm{~nm}$ gold particles (Nanoprobes) overnight at $4^{\circ} \mathrm{C}$. After several washes in $25 \mathrm{~mm}$ PBS, the sections were postfixed in $1 \%(\mathrm{v} / \mathrm{v})$ glutaraldehyde in PBS. Silver enhancement of the gold particles was performed using HQ Silver Enhancement kit (Nanoprobes). Subsequently, sections were incubated in the $\mathrm{ABC}$ Kit (Vector Laboratories). The peroxidase-labeled sections and the gold-silver-labeled sections were treated with $\mathrm{OsO}_{4}(1 \%$ in $0.1 \mathrm{M} \mathrm{PB})$, stained with $1 \%(\mathrm{w} / \mathrm{v})$ uranyl acetate, dehydrated in graded series of ethanol and propylene oxide (Polysciences) and flat-embedded in epoxy resin (Durcupan ACM; SigmaAldrich). After polymerization, 70-80 nm sections were cut using an ultramicrotome Reichert Ultracut S (Leica). The slices were examined using the LEO 906E transmission electron microscope (Zeiss) and images were acquired and analyzed by BioVision/VarioVision 3.2 software (Soft Imaging System; Olympus).

Electrophysiology. During recording, slices were perfused with the standard aCSF (ascorbic acid, myo-inositol, and sodium pyruvate were omitted) bubbled with $5 \% \mathrm{CO}_{2} / 95 \% \mathrm{O}_{2}$ or HEPES-based solution containing the following (in mM): $145 \mathrm{NaCl}, 2.5 \mathrm{KCl}, 1 \mathrm{MgCl}_{2}, 2 \mathrm{CaCl}_{2}, 25$ glucose, 10 HEPES, pH 7.3, bubbled with $\mathrm{O}_{2}$. Neurons were viewed using a Zeiss Axioskop FS2-plus with differential interference contrast optics and a $60 \times$ water-immersion objective. Postsynaptic principal cells in the MNTB were identified by their typical morphology (spherical cells, diameter $\sim 15-20 \mu \mathrm{m}$ ), their ability to generate an EPSC and, upon steady depolarization in current-clamp, a single action potential. Presynaptic terminals were filled with Lucifer yellow in each case and identified visually as a calyx surrounding the MNTB principal cell (Forsythe, 1994; Turecek and Trussell, 2001). For recordings from GBCs, parasagittal slices including the AVCN were prepared. Bushy cells were identified as oval cells with eccentric nuclei and a single bushy dendrite observed when labeled with Lucifer yellow in recording pipette or retrogradely with Alexa Fluor 488 dextran conjugates injected into the medial border of the MNTB area (Turecek and Trussell, 2002).

Borosilicate glass electrodes for whole-cell postsynaptic recording had resistances of 2-3 $\mathrm{M} \Omega$ when filled with pipette solution; series resistances during recordings were $<5 \mathrm{M} \Omega$ and were compensated electronically by $90 \%$. Presynaptic and postsynaptic cells were voltage-clamped to $0 \mathrm{mV}$ or $-70 \mathrm{mV}$, unless otherwise indicated. For recordings from presynaptic terminals, the electrodes were 5-6 $\mathrm{M} \Omega$, with series resistances of 10-15 $\mathrm{M} \Omega$, compensated by $90 \%$. Pipettes for presynaptic and postsynaptic whole-cell recording of glycine responses and mIPSCs contained the following (in mM): $125 \mathrm{CsMeSO}_{3}, 15 \mathrm{CsCl}, 5 \mathrm{EGTA}, 1 \mathrm{MgCl}_{2}, 10 \mathrm{HEPES}$, 4 ATP, 0.6 GTP, 10 phosphocreatine, and 0.4 Lucifer yellow, pH 7.25, 295 mOsm. Pipette solution for whole-cell recording of evoked IPSCs was supplemented with $2 \mathrm{~mm} \mathrm{~N}$-(2,6-dimethylphenylcarbamoylmethyl) triethylammonium chloride (QX314). Pipettes for recording EPSCs contained the following (in mM): $135 \mathrm{CsF}, 5 \mathrm{CsCl}, 5$ EGTA, 10 HEPES, 2 QX314, 4 ATP, 0.6 GTP, and 10 phosphocreatine, pH 7.25, 295 mOsm. Membrane voltages were corrected for pipette junction potentials.

Glycine receptor current responses were evoked by glycine applied by pressure ejection (Picospritzer III; General Valve). Pressure pipette parameters were similar for application of glycine to cell bodies and to terminals [3-4 $\mu \mathrm{m}$ pipette tips, placed $\sim 20 \mu \mathrm{m}$ from the cells, using 3-6 psi pressure $(1 \mathrm{psi}=6.89 \mathrm{kPa})]$. IPSCs and EPSCs were elicited by voltage pulses (100 $\mu \mathrm{s}, 5-10 \mathrm{~V}$ stimuli) delivered through a glass pipette. Current responses were recorded with an Axopatch 200B (Molecular Devices); signals were filtered at $1 \mathrm{kHz}$ (glycine application) or at $10 \mathrm{kHz}$ (synaptic currents), digitized at $2 \mathrm{kHz}$ (glycine application) or at $20 \mathrm{kHz}$ (synaptic currents), and acquired using pCLAMP software (Molecular Devices). 
Glycine-evoked responses were recorded in the presence of HEPES-based aCSF supplemented with $0.5 \mu \mathrm{M}$ tetrodotoxin (TTX), $10 \mu \mathrm{M}$ 6,7-dinitroquinoxaline-2,3-dione (DNQX), and $5 \mu \mathrm{M}$ 3-((R)-2-carboxypiperazin-4-yl)propyl-1-phosphonic acid (CPP) to block voltage-gated sodium channels and glutamateevoked conductances. IPSCs and EPSCs were recorded in the presence of $\mathrm{HCO}_{3}^{-}$-based aCSF supplemented either with $10 \mu \mathrm{M}$ DNQX and 5 $\mu \mathrm{M}$ (R)-CPP (evoked IPSCs) or with $0.5 \mu \mathrm{M}$ TTX (mIPSCs). Reagents were obtained from SigmaAldrich, Tocris Bioscience, and Alomone Labs.

Data analysis. Glycine-evoked responses and PSCs were analyzed using pClamp. The peaks of IPSCs and EPSCs were measured with respect to a baseline current just preceding the stimulus artifact. Exponential IPSC decays were fitted using the Chebyshev algorithm. Twenty IPSCs from each cell were fitted and the results averaged. To obtain a plateau current during the $100 \mathrm{~Hz}$ train of IPSCs, individual baselines preceding the last 10 IPSCs in a train were analyzed and averaged. The decay time of a train of IPSCs was quantified by fitting of decay of 10 averaged trains to a doubleexponential function. Glycinergic mIPSCs were identified based on their fast kinetics (decay time constant $<4 \mathrm{~ms}$; Awatramani et al., 2005b) and their sensitivity to strychnine $(0.3 \mu \mathrm{M})$. For each cell, mIPSCs were collected from $10 \mathrm{~min}$ long recordings acquired before, during, and after bath application of a drug. The results are presented as mean \pm SD with $n$ indicating the number of cells studied. For statistical comparison of the experimental data, paired Student's $t$ test was used. A probability level of $p<0.05$ was chosen to represent statistical significance.

\section{Results}

\section{Pharmacology of postsynaptic GlyRs in MNTB}

To reveal the subunit compositions of postsynaptic GlyRs in MNTB, we analyzed the sensitivity of glycine-evoked currents. One second puffs of $100 \mu \mathrm{M}$ glycine to the somata of principal cells (Fig. 1A) evoked strychnine-sensitive currents that reversed close to the chloride equilibrium potential of $-56 \mathrm{mV}$ ( $\mathrm{Wu}$ and Kelly, 1995; Kungel and Friauf, 1997; Turecek and Trussell, 2001, 2002; Price and Trussell, 2006). The responses had a mean maximal amplitude of $5.45 \pm 4.79 \mathrm{nA}(n=36)$ at a holding potential of $+10 \mathrm{mV}$. Picrotoxin (PTX; $50 \mu \mathrm{M}$ ), which blocks $\alpha$ homomeric GlyR but not $\alpha / \beta$ heteromeric GlyR (Schmieden et al., 1989; Lynch et al., 1995; Wang et al., 2006), did not significantly reduce the amplitudes of glycine-evoked currents (6.6 \pm $19.3 \%$ reduction, $n=10, p=0.348$; Fig. $1 B, F)$ suggesting the involvement of heteromeric GlyRs. To support this conclusion, postsynaptic GlyRs were also examined using ICS 205.930 (tropisetron), previously shown to potentiate responses of $\alpha / \beta$ heteromeric GlyRs activated by subsaturating concentrations of agonist (Chesnoy-Marchais, 1996; Supplisson and Chesnoy-Marchais, 2000; Yang et al., 2007b). We found that the maximal amplitudes of $15 \mu \mathrm{M}$ glycine-evoked responses $(0.33 \pm 0.23 \mathrm{nA}, n=6)$ were potentiated nearly threefold in the presence of $1 \mu \mathrm{M}$ ICS 205.930 $(0.90 \pm 0.76 \mathrm{nA} ; p=0.047$; Fig. $1 C)$. Thus, the results are consistent with an $\alpha / \beta$ heteromeric composition of postsynaptic GlyRs in the MNTB.

Our next experiments identified pharmacologically the subtype of $\alpha$-subunit participating in postsynaptic GlyR heteromers. We used $5 \mu \mathrm{M}$ cyanotriphenylborate (CTB), shown to preferen-
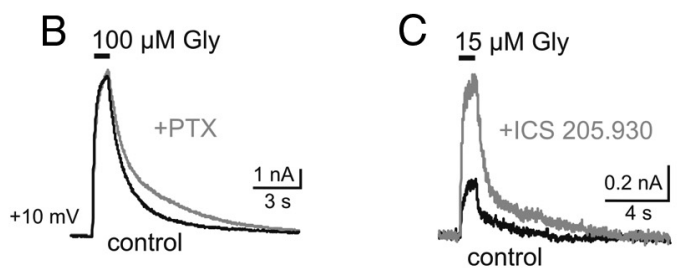

$\mathrm{F}$
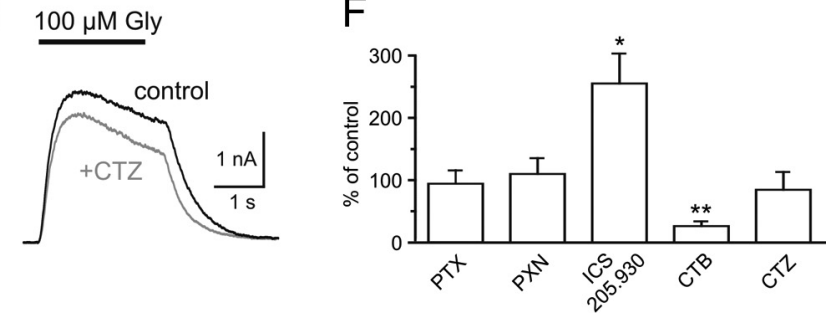

Figure 1. MNTB principal cells express functional $\alpha 1 / \beta$ heteromeric GlyRs. $\boldsymbol{A}$, The configuration for recording of glycine-evoked GlyR currents recorded in the absence (control) or presence of $5 \mu \mathrm{M}$ CTB at 1 min intervals. MNTB slices were incubated in CTB (he first combined applications of glycine and CTB (i). CTB produced a steady-state inhibition of GlyR absence (control) or presence of $100 \mu \mathrm{M}$ CTZ. $\boldsymbol{F}$, Bar graph summarizes the effects of subunit-specific drugs on glycine-evoked

tially block the $\alpha 1$-subunit-containing receptors in a voltagedependent manner (Rundström et al., 1994). As shown in Figure $1 D, 5$ s coapplication of CTB and glycine to MNTB principal cells clamped at $+10 \mathrm{mV}$ evoked current responses characterized by a strongly accelerated decay phase following a relatively unaffected peak response. Subsequent coapplications of CTB and glycine evoked currents that were strongly inhibited. The maximal amplitude of currents after 10 coapplications was reduced to $26.1 \pm$ $7.7 \%$ of control $(n=8, p=0.008$; Fig. $1 D, F)$. The inhibition was relieved when the membrane potential was held at $-70 \mathrm{mV}$ and glycine was applied in CTB-free solution (data not shown). This observation was consistent with use-dependent block of GlyRs by CTB (Zhorov and Bregestovski, 2000) and suggested that postsynaptic GlyRs in MNTB contained $\alpha 1$-subunits.

A possible contribution of other $\alpha$-subunit subtypes was tested using cyclothiazide (CTZ; $100 \mu \mathrm{M})$ and picrotoxinin (PXN; $10 \mu \mathrm{M})$, previously observed to specifically inhibit $\alpha 2$ and $\alpha 3$-subunit-containing GlyRs, respectively (Yang et al., 2007a; Zhang et al., 2008). Current responses evoked by $5 \mathrm{~s}$ applications of glycine to MNTB principal cells were not significantly reduced in the presence of CTZ (Fig. $1 E, F$; control: $4.37 \pm 1.77 \mathrm{nA}, \mathrm{CTZ}: 3.88 \pm 2.53 \mathrm{nA} ; n=6 ; p=0.378$ ). The low sensitivity of the responses to the drug indicated that $\alpha 2$-subunit did not significantly contribute to postsynaptic GlyR population. Application of PXN also did not affect the amplitude of glycine-induced currents (Fig. $1 F$; control: $3.06 \pm 2.41 \mathrm{nA}$, PXN: $3.09 \pm 2.08 \mathrm{nA} ; n=6, p=0.928)$ arguing against the presence of $\alpha 3$-subunits in postsynaptic GlyRs. We therefore conclude that functional GlyRs expressed by MNTB principal cells are formed as $\alpha 1 / \beta$ heteromers.

\section{Pharmacology of synaptically activated receptors}

To reveal possible differences between synaptic and extrasynaptic GlyRs in MNTB principal cells, we examined the pharmacology of synaptic responses. IPSCs were first elicited by low-frequency $(0.1 \mathrm{~Hz})$ stimulation of glycinergic fibers (Fig. $2 A)$ at physiological temperature (Banks and Smith, 1992; Turecek and Trussell, 2001; Awatramani et al., 2004). IPSCs reached maximal ampli- 
A

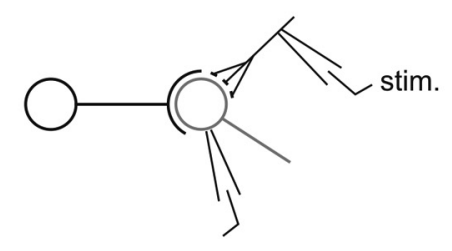

B

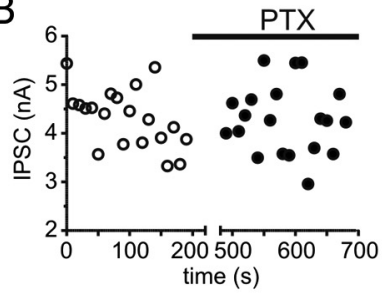

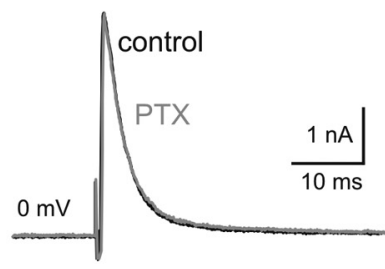

C

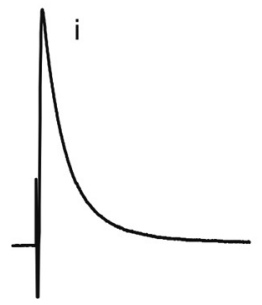

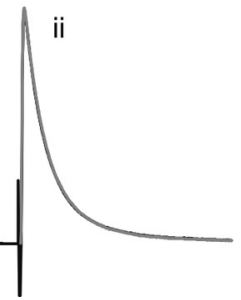
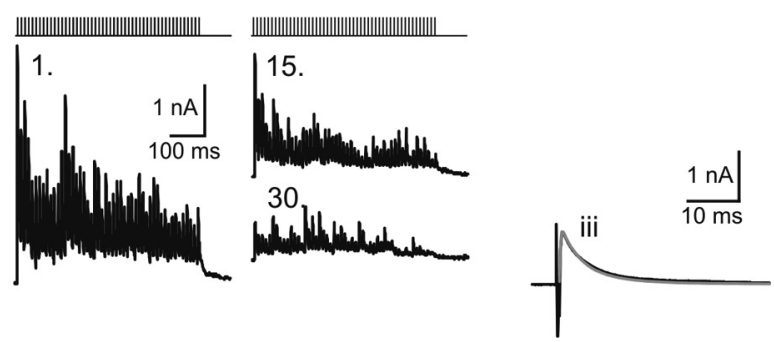

Figure 2. Synaptic and extrasynaptic GlyRs in MNTB principal cells have similar subunit compositions. $\boldsymbol{A}$, Configuration for recording of glycinergic IPSCs from MNTB principal cells. $\boldsymbol{B}$, Left, The plot shows maximal amplitudes of IPSCs recorded in the absence $(\bigcirc)$ or in the presence $(-)$ of $50 \mu \mathrm{m}$ PTX. Right, Superimposed traces obtained by averaging of 20 control IPSCs (black) or 20 IPSCs recorded in PTX-treated cells (gray). C, Averages of 20, low-frequency ( $0.1 \mathrm{~Hz}$ ) IPSCs, recorded in the absence (i) or presence of CTB, before (ii) and after (iii) 30 trains of 50 IPSCS ( $100 \mathrm{~Hz}$ ) elicited every 20 s. For comparison of time courses, the control IPSC (i) was normalized and superimposed as gray trace at the IPSCs recorded in the presence of CTB (ii and iii, black). Note that gray and black traces overlap completely. The numbers at trains denote their sequence of recording. Stimulus artifacts were removed in the train traces.

A

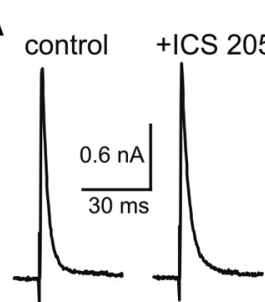

C

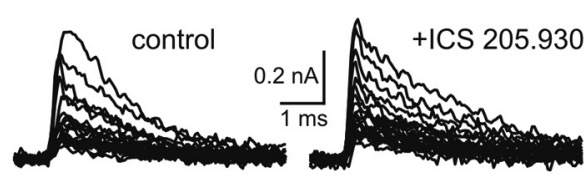

$\mathrm{F}$

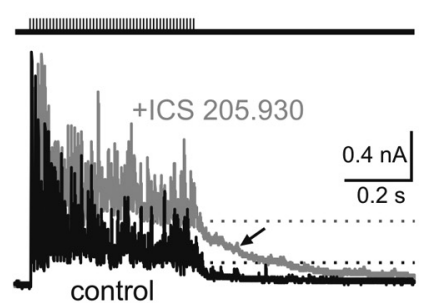

$\mathrm{D}$

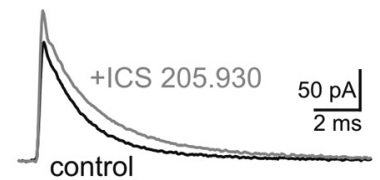

B

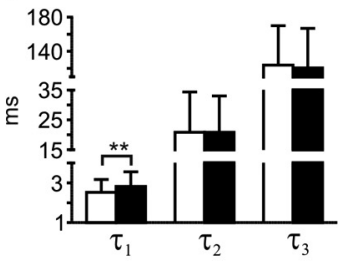

$\mathrm{E}$

$\mathrm{H}$

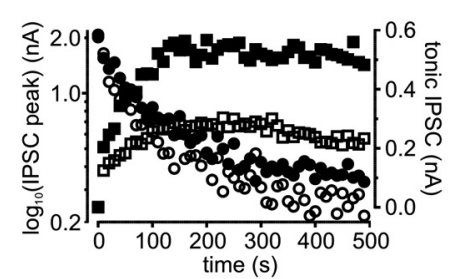

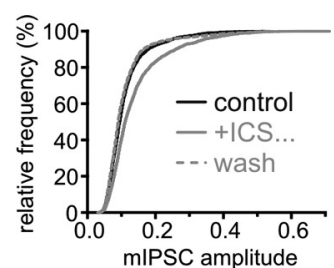
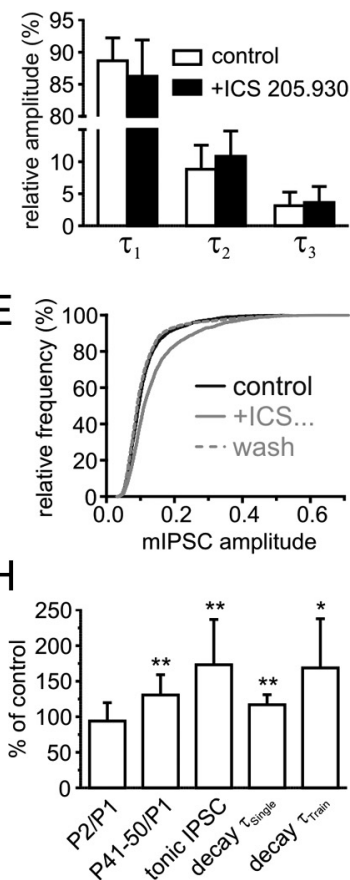

Figure 3. Synaptic GlyRs mediate phasic IPSCS. A, Low-frequency IPSCs recorded in the absence (Control) or presence of $1 \mu \mathrm{m}$ ICS 205.930, as indicated. Insets emphasize fits of three-exponential curves (gray) to early and late phases of IPSC decay [fitted time constants (relative amplitudes) are $2.2 \mathrm{~ms}(94.9 \%), 23.6 \mathrm{~ms}(3.3 \%)$, and $114.2 \mathrm{~ms}$ ( $1.8 \%)$ for control and $3.0 \mathrm{~ms}(94.9 \%), 17.8 \mathrm{~ms}$ (3.6\%), and $109.3 \mathrm{~ms}$ (1.5\%) for ICS 205.930]. B, Values of the time constants (left bar graph) and relative magnitudes (right bar graph) of each component in the fitted curves in control and ICS 205.930 for three-exponential fits to decay of low-frequency IPSCS. C, Examples of glycinergic mIPSCs recorded from an MNTB principal cell in the absence (Control) or presence of ICS 205.930 (20 mIPSCs are shown for each treatment). D, Superimposed traces represent averages of 594 events (Control, black) or 560 events (ICS 205.930, gray) obtained from the same cell shown in C. Note that the drug increased both the maximal amplitude and the decay time of mIPSCS. E, Normalized cumulative distributions of maximal mIPSC amplitudes obtained from all eight cells analyzed. In each cell, the data were collected from 10 min long recording periods before (black; 3199 events), during (solid gray; 2829 events), or 10 min after (broken gray; 2923 events) bath application of ICS 205.930. The drug caused a significant shift of mIPSC amplitudes toward higher values $(p<0.001$, Kolmogorov-Smirnov test). $\boldsymbol{F}$, The traces show trains of 50 IPSCs stimulated at $100 \mathrm{~Hz}$ in the absence (Control, black trace) or presence of $1 \mu \mathrm{m}$ ICS 205.930 (gray trace). The arrow marks the decay after the train in ICS 205.930 and the dashed lines indicate levels of the tonic IPSC. G, The plot shows the magnitude of the effects of ICS 205.930 on trains of IPSCS. Data points represent average values of peaks of phasic IPSCS (circles, left $y$-axis) or currents just preceding the phasic IPSCs (squares, right $y$-axis) obtained from 10 trains recorded every $20 \mathrm{~s}$ in the absence (open symbols) or presence of the drug (filled symbols). The data are from the same cell as in $\boldsymbol{F}$. $\boldsymbol{H}$, Bar graph summarizes the effects of ICS 205.930 on trains of IPSCS. P denotes the peak of the phasic IPSC measured from the current level just preceding the stimulus artifact. $\tau_{\text {Single }}$ and $\tau_{\text {Train }}$ represent amplitude-weighted mean time constants of decays of single low-frequency IPSCs or trains of IPSCs. The data are collected from 8 to 14 cells. ${ }^{*} p<0.05$ or ${ }^{* *} p<0.01$ (paired $t$ test). 
tudes of $2.96 \pm 2.48 \mathrm{nA}$ at $0 \mathrm{mV}(n=28)$ with $0.6 \pm 0.2 \mathrm{~ms}$ rise time. Similar to exogenous glycine-evoked responses, the amplitudes of IPSCs were not significantly reduced in the presence of PTX (to $96.3 \pm$ $11.9 \%, n=8, p=0.201$ ) suggesting a heteromeric composition of synaptic GlyRs (Fig. 2B). In contrast to glycine-evoked responses, the maximal amplitude of IPSCs was unchanged in the presence of CTB (Fig. 2C). We assumed that unlike the pharmacological stimulation of GlyRs, synaptically released glycine only briefly activated GlyR-associated ion channels, insufficient to permit a significant block by the drug. To prolong the activation time of synaptic GlyRs and thereby increase their sensitivity to CTB, IPSCs were repetitively stimulated at high frequency. Figure $2 C$ shows a strong reduction (to $37.1 \pm 18.4 \%, n=6, p=$ 0.032 ) of the amplitude of single IPSC recorded after 30 trains of 50 IPSCs elicited at $100 \mathrm{~Hz}$ in the presence of CTB. This indicated that the receptors actually were sensitive to the drug and implied an involvement of the $\alpha 1$-subunits. The decay time of single IPSCs recorded after the trains was not significantly changed by CTB (Fig. 2C). In control experiments, 30 trains delivered in the absence of CTB did not lead to significantly reduced peak amplitude of single low-frequency IPSCs recorded after the trains (by $-0.4 \pm 16.1 \%$, $n=9, p=0.980$ ) (data not shown). We also tested effects of CTB on the amplitude of spontaneous glycinergic mIPSCs (see Materials and Methods). Twenty minute long exposure to CTB of MNTB principal cells held at $0 \mathrm{mV}$ caused a decrease of the average mIPSC amplitude from $142.3 \pm 8.0$ to $93.2 \pm 22.4 \mathrm{pA}(n=4$, $p=0.016)$. This observation was consistent with the data obtained from evoked IPSCs and indicated the presence of $\alpha 1$ subunits in postsynaptic receptors.

Unlike effects on responses to a low concentration of glycine, the amplitude of low-frequency IPSCs was not significantly increased in the presence of ICS 205.930 (by $-1.9 \pm 10.1 \%, n=6, p=0.438$ ) (Fig. $3 A$ ). The drug, however, reversibly increased average amplitude of glycinergic mIPSCs $(124.1 \pm 36.3 \mathrm{pA})$ by $25.0 \pm 10.2 \%(n=8, p=0.004)$ (Fig. $3 C-E$ ). Also, the amplitudes of evoked IPSCs recorded at higher stimulus rates were potentiated by ICS 205.930. Figure $3 F$ shows trains of 50 IPSCs elicited at $100 \mathrm{~Hz}$ in the absence or presence of the modulator. During control trains, IPSCs gradually depressed, reaching a steady-state level (calculated as the average of the last 10 IPSCs), which was $20.9 \pm 7.9 \%(n=14)$ of the first IPSC. In ICS 205.930, the IPSCs declined less, to $26.2 \pm 8.3 \%$ of the first IPSC $(p=0.002$; Fig. $3 F-H)$. In contrast, the ratio between the peaks of the second and the first IPSCs in a train was not significantly changed in the presence of ICS 205.930 (from $0.83 \pm 0.16$ to $0.76 \pm 0.19, p=0.321$; Fig. $3 H$ ) suggesting that the effect of the drug did not result from a presynaptic mechanism. Thus the data indicate that synaptically activated GlyRs are sensitive to ICS 205.930. Together, the results are consistent with a $\alpha 1 / \beta$ heteromeric formation of synaptic GlyRs. Responses of these receptors showed similar pharmacological properties as currents induced in the whole cells by exogenous glycine application. We therefore suggest that the subunit compositions of extrasynaptic GlyRs and synaptic GlyRs in MNTB principal cells are similar.

Interestingly, IPSCs at $100 \mathrm{~Hz}$ did not fully decay to baseline between each stimulus, thus generating a tonic IPSC during the train (Fig. 3F) (Singer and Berger, 2000; Telgkamp and Raman, 2002). This enhanced baseline current was quantified by measur- 

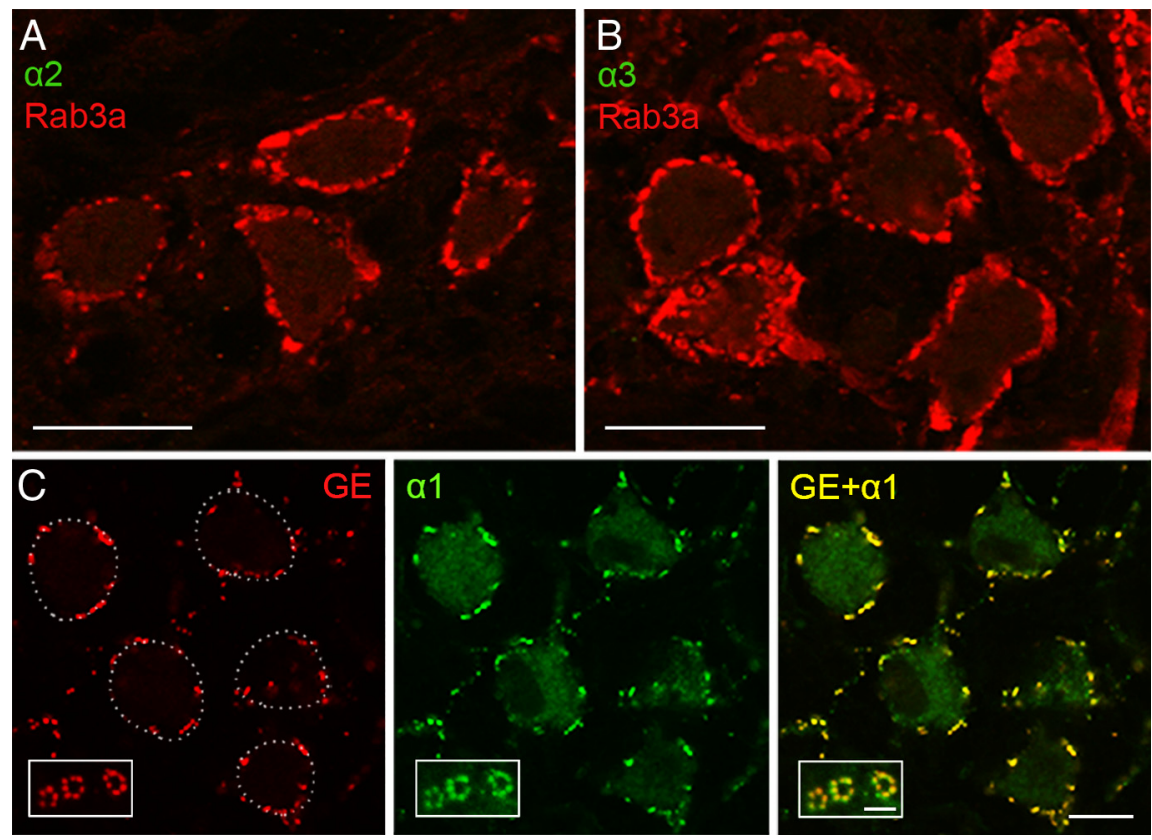

Figure 5. GlyR $\alpha 1$ - and $\beta$-subunits colocalize in postsynaptic neurons of adult MNTB. $A, B$, Single confocal plane images of an MNTB slice double labeled with Rab3a (red) and with GlyR $\alpha 2$ or $\alpha 3$ antibodies (green). No specific labeling associated with GlyRs was found. C, MNTB principal cells double labeled for gephyrin (GE; red) and for GlyR $\alpha 1$-subunit (green) showing a high degree of colocalization of both fluorescent signals (right). Inset shows rosettes of GlyR clusters at a higher magnification. The dashed line indicates the cell surface. Scale bars: $\boldsymbol{A}, \boldsymbol{B}, 20 \mu \mathrm{m} ; \boldsymbol{C}, 8 \mu \mathrm{m}$; inset, $4 \mu \mathrm{m}$.

ing current amplitudes just preceding each of the last 10 stimulation artifacts in a train. ICS 205.930 elevated the tonic IPSC from $0.64 \pm$ $0.73 \mathrm{nA}$ to $0.88 \pm 0.91 \mathrm{nA}(n=11, p=0.007)$ (Fig. $3 F-H)$. The increase was accompanied by a significant prolongation of the recovery of the last IPSC in a train (Fig. $3 F$ ). The recovery phase was fitted to double exponential function and a mean amplitude-weighted time constant was then calculated. The time constant was increased from a control value of $0.20 \pm 0.11 \mathrm{~s}$ to $0.31 \pm 0.19 \mathrm{~s}$ in the presence of ICS $205.930(n=8, p=0.017)$. The prolongation of the decay likely reflected the slow removal of accumulated glycine after the train, as the mean decay constant of low-frequency IPSCs fitted to three exponential functions was much less modified by the drug (control: 7.0 $\pm 2.3 \mathrm{~ms}$, ICS 205.930: $8.1 \pm 2.4 \mathrm{~ms}, n=10, p=0.003$ ) (Fig. $3 A, B$ ). This result suggested that the sensitivity of the cells to glycine accumulation during repetitive stimulation was significantly enhanced by ICS 205.930. It also suggests that postsynaptic GlyRs normally do not fully respond to accumulated glycine and its presence could be unmasked after experimental increase of affinity of postsynaptic GlyRs.

\section{Localization of postsynaptic GlyRs in MNTB of adult rats}

Localization and subunit composition of GlyRs in adult MNTB was studied using immunohistochemical methods. To discriminate between presynaptic and postsynaptic MNTB structures, we labeled calyces of Held with antibodies raised against calretinin (CR) or Rab3a (Fig. 4A) (Lohmann and Friauf, 1996; Felmy and Schneggenburger, 2004). MNTB principal cells were labeled either with calbindin (CaBP) antibody (Fig. $4 F$ ) or by retrograde tracer, the BDA (Fig. 4G) (Veenman et al., 1992; Friauf, 1993; Felmy and Schneggenburger, 2004). GlyRs were labeled with mAb2b primary antibody recognizing an extracellular epitope (the first $10 \mathrm{~N}$-terminal amino acids) of the $\alpha 1$-subunit (Pfeiffer et al., 1984). The staining revealed membrane-delimited clusters, which did not colocalize with either anti-Rab3a or anti-CR fluo- rescence signals, demonstrating a postsynaptic locus of the receptors (Fig. $4 B, C)$. Almost all of the clusters were apposed to vesicular inhibitory amino acid transporter (vGAT)-positive nerve endings (Fig. 4E), and many were organized in the striking rosettes typical for GlyRs reported in other cell types (Fig. 4D) (Alvarez et al., 1997; Wojcik et al., 2006). We counted numbers of rosettes per cell in coronal sections cut through the central region of MNTB, finding in 161 of 192 cells $3.7 \pm 2.4$ rosettes/cell (range 1-12, five rats). Interestingly, the anti- $\alpha 1$ positive clusters were also observed on dendritic shafts and proximal parts of postsynaptic axons, extending up to $\sim 20$ $\mu \mathrm{m}$ from the soma (Fig. $4 E-G$ ), suggesting localization of GlyRs at the axon initial segment (Smith et al., 1998; Korada and Schwartz, 1999).

To reveal the presence of other subtypes of $\alpha$-subunit in mature MNTB neurons we have labeled brainstem slices with primary antibodies raised against $\alpha 2$ - or $\alpha 3$-subunits. None of the antibodies provided a specific labeling of MNTB neurons (Fig. 5A,B), whereas these antibodies did specifically label $\alpha 2$ - and $\alpha 3$ subunits in mouse retina (data not shown). This suggested that $\alpha 2$ and $\alpha 3$ proteins were not significantly expressed by postsynaptic MNTB neurons.

The next experiments determined the localization of GlyR $\beta$-subunit in MNTB neurons of adult rats. The presence of GlyR $\beta$-subunit was examined using the mAb7a antibody raised against the $\beta$-subunit-associated protein, gephyrin (Kirsch et al., 1991), previously localized in MNTB of juvenile mice (Leao et al., 2004). The antibody labeled membrane-delimited clusters and codistributed with the $\alpha 1$ GlyR signals (Fig. 5C). The colocalization was analyzed for all identified principal cells in 11 MNTB sections and $96.4 \pm 7.9 \%$ coincidence was found. The clusters occupied both somatic and dendritic compartments and were also present at postsynaptic axons (data not shown). While we cannot exclude that gephyrin-positive clusters also contained $\mathrm{GABA}_{\mathrm{A}}$ receptors (Fritschy et al., 2008), we suggest that the colocalization of gephyrin and GlyR $\alpha 1$ in mature MNTB principal cells indicated the presence of heteromeric postsynaptic GlyRs as the $\alpha 1$-subunits were found to distribute diffusely in the absence of gephyrin (Feng et al., 1998).

\section{Pharmacology of GlyRs in calyces and bushy cells}

We next explored the subunit composition of GlyRs expressed by the calyces of Held, as well as by their parent cell bodies, the GBCs of the ventral cochlear nucleus (Wu and Oertel, 1986). Whole-cell recordings were made on calyces, as described previously (Turecek and Trussell, 2001) (Fig. 6A). In contrast to postsynaptic glycine responses, glycine-evoked currents recorded from calyces of Held $(0.11 \pm 0.08 \mathrm{nA}$ at $0 \mathrm{mV}, n=20)$ were markedly reduced in the presence of PTX (64.2 $\pm 12.5 \%$ reduction, $n=8, p=0.016$; Fig. $6 B, E)$. The drug also suppressed presynaptic responses recorded at $-80 \mathrm{mV}$ by $71.4 \pm 15.1 \%(p=0.005)$ (data not shown). This was consistent with voltage-independent block of $\alpha$ homomeric GlyRs by PTX (Lynch et al., 1995; Wang et al., 2006) and suggested that 
calyceal GlyRs lack the $\beta$-subunit. The receptors also showed a high sensitivity to CTB (Fig. 6C,E). Maximal amplitudes of their current responses were nearly eliminated after two consecutive coapplications of glycine and CTB (control: $75.1 \pm 49.0$ pA; CTB: $8.0 \pm 3.3 \mathrm{pA} ; n=5, p=0.041)$. Finally, the receptors showed only slight sensitivity to PXN $(10 \mu \mathrm{M})$, with inhibition of only $20.3 \pm 7.1 \%(n=5, p=0.068$; Fig. $6 D, E)$. Therefore, we conclude that calyceal GlyRs are formed as $\alpha 1$ homomers.

To determine a physiological relevance of calyceal $\alpha 1$ homomers, we tested their involvement in the facilitation of glutamate release previously reported for presynaptic GlyRs in the calyx of Held (Turecek and Trussell, 2001). We recorded glutamatergic EPSCs elicited every 20s in MNTB principal cells held at $-60 \mathrm{mV}$ (Fig. $6 F$ ). Application of glycine $(100 \mu \mathrm{M})$ evoked a gradual elevation of EPSC amplitude by $31.7 \pm 9.0 \%$ $(n=7, p=0.003$; Fig. $6 G, H)$. When EPSCs were stimulated with high-frequency trains (10@100 Hz), the potentiation of the first EPSC in a train was accompanied by a greater use-dependent reduction of subsequent EPSCs (Fig. 6I). This increase in short-term depression of EPSCs was consistent with an enhanced glutamate release probability by presynaptic GlyRs (Turecek and Trussell, 2001; von Gersdorff and Borst, 2002; Awatramani et al., 2005a; Hori and Takahashi, 2009). The modulatory effects of glycine were significantly attenuated when the agonist was coapplied together with $50 \mu \mathrm{M}$ PTX (Fig. 6G-J). The potentiation of lowfrequency EPSCs dropped to $12.0 \pm$ $7.7 \%(p=0.003)$ and the depression of high-frequency EPSCs was relieved to levels insignificantly different from those obtained in the absence of glycine (Fig. 6I,J). Thus the data show that a mechanism of the glycine-induced EPSC facilitation was sensitive to PTX suggesting that presynaptic $\alpha 1$ homomeric GlyRs can modulate release of glutamate from the calyx.

The composition of GlyRs expressed on the soma of GBCs of the ventral cochlear nucleus was also examined. Glycine-evoked currents were recorded from labeled cell bodies voltage-clamped at $+10 \mathrm{mV}$ (Fig. $7 A, B$ ). Unlike the GlyR of nerve terminals, somatic receptors reacted in a way typical for $\alpha / \beta$ heteromers. Maximal amplitudes of their responses were not significantly altered in the presence of PTX (from $10.85 \pm 3.49 \mathrm{nA}$ to $10.47 \pm 3.85 \mathrm{nA}, n=6, p=0.484$; Fig. $7 C$ ), while they were potentiated by ICS 205.930 (from $1.01 \pm 1.29 \mathrm{nA}$ to $2.18 \pm 2.52 \mathrm{nA}, n=7$, $p=0.049$; Fig. 7D). The receptors contained the $\alpha 1$-subunits as current responses to 10 coapplications of glycine and CTB were reduced by $69.6 \pm 16.9 \%(n=6, p=0.018$; Fig. $7 E)$. CTB did not induce any significant inhibition of currents recorded from somata of bushy cells held at $-80 \mathrm{mV}$ (data not shown). Altogether, the data
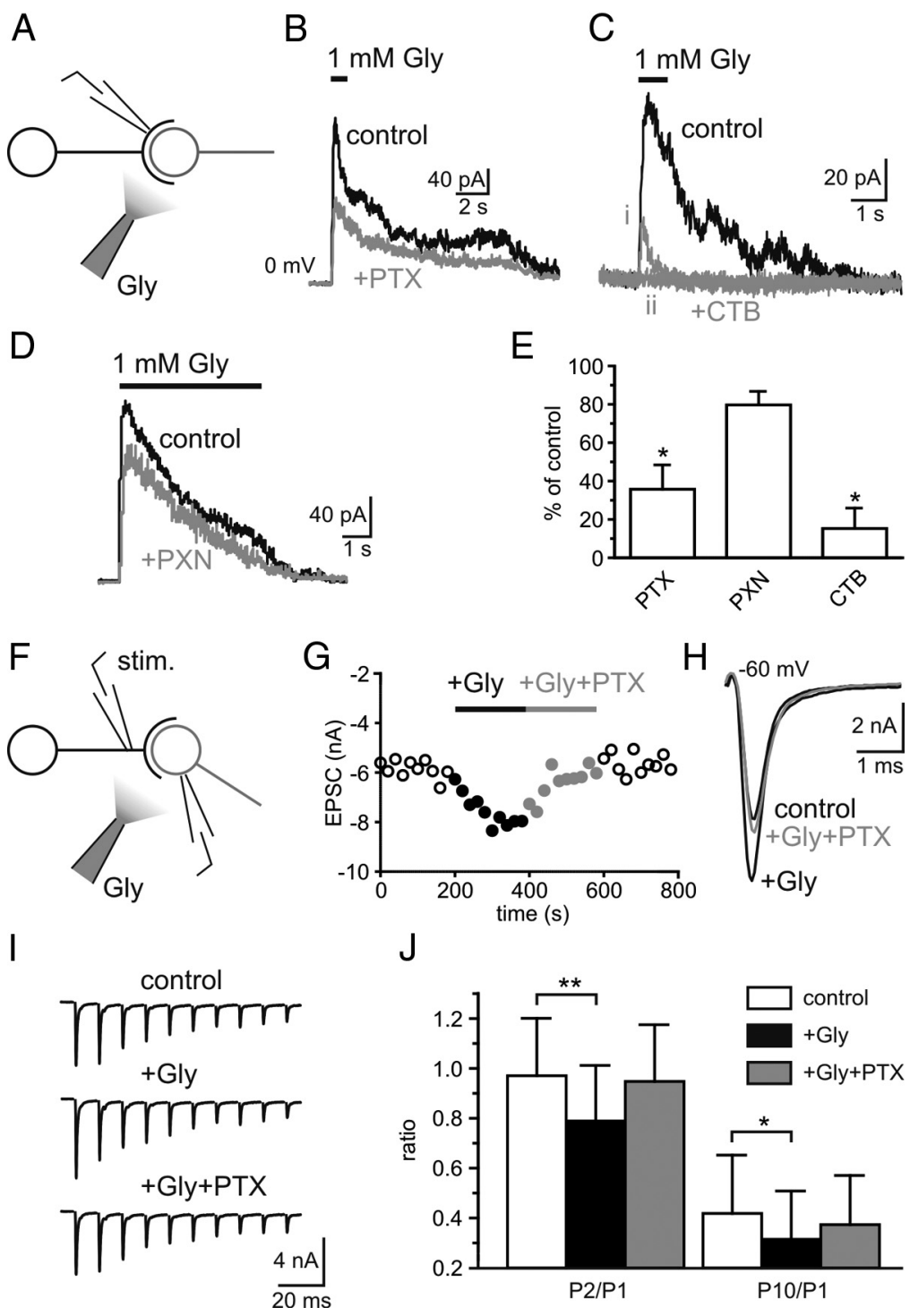

Figure 6. $\alpha 1$ homomeric GlyRs on calyces of Held mediate slow presynaptic facilitation. $\boldsymbol{A}$, The scheme shows recording configuration. $\boldsymbol{B}$, GlyR current responses obtained by recording from a calyx terminal in the absence (Control) or in the presence of $50 \mu \mathrm{M}$ PTX. C, Calyceal responses evoked by glycine applications repeated at $1 \mathrm{~min}$ intervals in the absence (control) or presence of $5 \mu \mathrm{M}$ CTB. CTB eliminated GlyR responses after two consecutive coapplications with glycine (i, ii). D, Representative traces of calyceal GlyR currents recorded in the absence (Control) or in the presence of $10 \mu \mathrm{m}$ PXN. E, Summary of effects of subunit-specific drugs on glycine-evoked responses obtained from 18 calyces. $\boldsymbol{F}$, Configuration for recording of EPSCs from MNTB principal cells. $\boldsymbol{G}$ amplitudes of control EPSCS $(O)$ and EPSCs obtained in the presence of $100 \mu \mathrm{m}$ glycine $(O)$ or in the presence of $100 \mu \mathrm{m}$ glycine and $50 \mu \mathrm{M}$ PTX (O). Note relatively slow time courses of both the onset and the offset of glycine-induced EPSC potentiation. $\boldsymbol{H}$, Superimposed traces show averages of five consecutive EPSCs in the absence (Control) or presence of glycine $(+\mathrm{Gly})$ or in trains elicited in 1 min intervals are shown. J, PTX-sensitive effects of glycine on ratios between the second (P2) and the first (P1) EPSCs in a train or between the last (P10) EPSC and P1. ${ }^{*} p<0.05$ or ${ }^{* *} p<0.01$ (paired $t$ test).

reveal differences in the properties of glycine responses obtained from somatic and calyceal compartments and suggest that GlyRs have different molecular composition in these areas. Somatic receptors appear to be formed as heteromers composed of $\alpha 1$ - and $\beta$-subunits whereas the receptors at nerve terminals are largely homomers of $\alpha 1$-subunits.

\section{Presynaptic GlyRs at mature calyx of Held synapse}

Our electrophysiological experiments suggest that presynaptic and postsynaptic GlyRs at the calyx of Held synapse differ with respect to the presence of the $\beta$-subunit. It is well accepted that binding of GlyR $\beta$-subunit to gephyrin is required for anchoring 
A

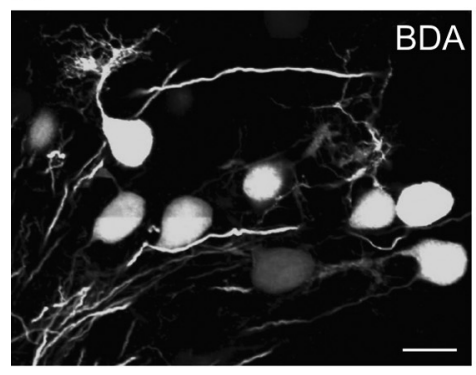

B

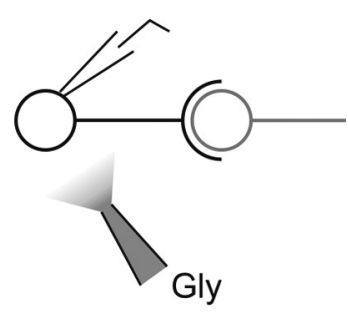

C
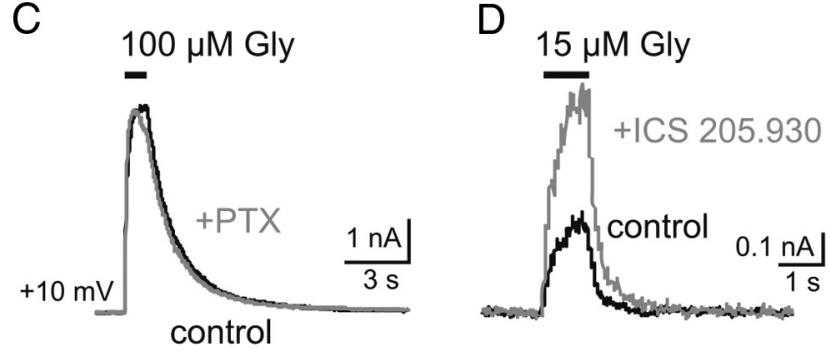

E

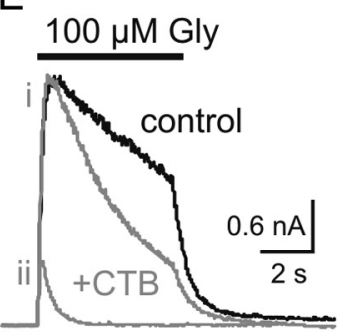

$\mathrm{F}$

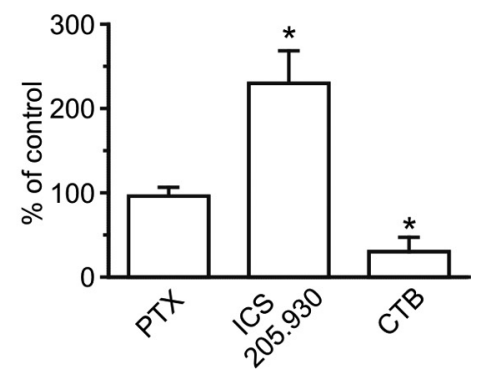

Figure 7. GBCs contain functional $\alpha 1 / \beta$ heteromeric GlyRs. $A, A Z$-series projection of five images through the AVCN shows GBCs, retrogradely labeled with BDA. Scale bar, $20 \mu \mathrm{m} . \boldsymbol{B}$, Configuration for recording of glycine-evoked currents from the soma of a GBC. C, D, GlyR currents recorded from GBCs in the absence (Control) or presence of $50 \mu \mathrm{m}$ PTX or $1 \mu \mathrm{m} \mathrm{ICS}$ 205.930, respectively. $\boldsymbol{E}$, GlyR currents recorded at 1 min intervals in the absence (control) or presence of $5 \mu \mathrm{m}$ CTB. Responses to the first and the tenth combined applications of glycine and CTB are shown (i, ii). $\boldsymbol{F}$, Summary of the effects of subunit-specific drugs on glycine-evoked responses obtained from $19 \mathrm{GBCs} .{ }^{*} p<0.05$ (paired $t$ test).

and concentration of the receptors at postsynaptic sites (Kneussel and Betz, 2000b; Moss and Smart, 2001; Kneussel and Loebrich, 2007; Fritschy et al., 2008). Calyceal GlyRs lacking the $\beta$-subunit would therefore be expected to have a diffuse distribution in presynaptic membrane. To test this, pre-embedding immunogold labeling of calyceal GlyRs was investigated by high-resolution electron microscopy (Triller et al., 1985; Kulik et al., 2003). To help to distinguish between presynaptic and postsynaptic localization of immunogold particles, we used rabbit primary antibody recognizing an intracellular epitope of the GlyR $\alpha 1$-subunit. The antibody labeled GlyRs on MNTB principal cells with the pattern similar to what we have found using the standard $\mathrm{mAb} 2 \mathrm{~b}$ antibody (Fig. $8 A$ ). Figure $8 B$ shows an example of a cross section through a mature calyx of Held synapse. Calyceal nerve terminals were identified as vGluT1-positive structures surrounding MNTB principal cells (Smith et al., 1998; Billups, 2005). Immunogold particles had a membrane-delimited localization in calyceal processes (Fig. $8 C, C^{\prime}$ ). The average distance between the middle of an immunogold particles and the inner edge of presynaptic membrane, $19.6 \pm 11.6 \mathrm{~nm}$, was similar to that found in

spinal cord neurons (Triller et al., 1985) and suggested that immunogold particles specifically labeled presynaptic $\alpha 1$ GlyR subunits. In three dimensionally reconstructed terminal, the immunoparticles appeared to have a dispersed horizontal distribution showing no apparent association to synaptic sites (Fig. $8 D$ ). In contrast, postsynaptic immunogold particles were densely packed in symmetrical synaptic contacts between vGluT1-immunonegative, putative inhibitory, nerve terminals, and somata of principal cells (Fig. 8E). Moreover, single particles located outside of inhibitory synapses were occasionally observed suggesting a presence of extrasynaptic GlyRs on MNTB principal cells (Fig. 8C, $C^{\prime}$ ). Clustered distribution of immunogold particles in postsynaptic membrane was also observed when we used the anti-gephyrin antibody while no specific labeling of gephyrin was found in presynaptic nerve terminals (Fig. $8 F$ ).

The final set of experiments sought to determine the subunit composition of somatic GlyRs of mature GBCs using confocal microscopy. We observed a punctate staining pattern of anti- $\alpha$ limmunoreactivity (mAb2b) showing no colocalization with anti-Rab3a fluorescence signals (Fig. 9A). Neither $\alpha 2$ - nor $\alpha 3$-subunit antibodies provided a specific labeling in GBC bodies (data not shown) suggesting that these subunits do not significantly contribute to the formation of GlyRs in these cells. On the other hand, cell bodies were strongly immunoreactive for gephyrin (Fig. 9B) (Lim et al., 1999, 2000). Anti- $\alpha 1$ and anti-gephyrin fluorescence signals were tightly colocalized suggesting that GlyRs expressed by GBCs contained $\beta$-subunits (data not shown). Thus, in contrast to the $\alpha 1$-subunit, GlyR $\beta$-subunit is differently distributed among somatic and nerveterminal compartments of bushy cells. Together, the immunocytochemical data are consistent with our electrophysiology findings, and indicate that nerve terminals of GBCs contain $\alpha 1$ homomeric GlyR, while postsynaptic MNTB cells and presynaptic soma express $\alpha 1 / \beta$ heteromeric GlyRs.

\section{Discussion}

Subcellular distribution of GlyR subunits in MNTB neurons All GlyRs of MNTB and bushy cells contained the $\alpha 1$-subunit, but with distinctly different distributions depending upon their membrane compartment: receptors on somata or dendrites were clustered, whereas GlyRs in calyceal nerve terminals displayed a diffuse membrane distribution. This difference was accompanied by a differential distribution of GlyR $\beta$-subunits into presynaptic and postsynaptic compartments. The $\beta$-subunit-associated protein, gephyrin, is an important for targeting and anchoring of GlyR subunits at postsynaptic sites (Kneussel and Loebrich, 2007; Fritschy et al., 2008; Specht and Triller, 2008; Dumoulin et al., 2009). Our examination of adult rat MNTB slices using immunoelectron microscopy revealed an accumulation of gephyrin at postsynaptic sites, whereas no gephyrin was detected in presynaptic terminals. The $\alpha 1$ homomeric form of presynaptic GlyRs and the diffuse distribution of subunits could therefore result from the absence of gephyrin in the calyx. This hypothesis is supported by reports showing that inactivation of the gephyrin gene leads to diffusely distributed $\alpha 1$ homomeric receptors in cultured neurons (Feng et al., 1998).

Numerous mechanisms of gephyrin trafficking, targeting, and maintenance have been explored and many appear to depend on neuronal activity (Kneussel and Betz, 2000b; Maas et al., 2009; Bausen et al., 2010; Charrier et al., 2010; Tyagarajan et al., 2011). It is therefore possible that in adult calyces of Held, membrane gephyrin is removed due to an as yet unidentified mechanism triggered by 
sensory activity. Previously, we have found that some GlyR channels expressed in immature rat calyces before the onset of hearing open to low-conductance states characteristic for $\alpha / \beta$ heteromeric receptors (Turecek and Trussell, 2002). This might mean that gephyrin and/or $\beta$-subunit could be expressed in immature calyces and that their absence in presynaptic terminals is not a general phenomenon. Additional experiments showing developmental regulation of gephyrin and/or $\beta$-subunits in the calyx of Held are needed to determine whether these proteins are removed as synapses mature.

In contrast to the $\beta$-subunit, the $\alpha 1$ subunit is a major component of both presynaptic and postsynaptic GlyRs in MNTB neurons. Previous reports demonstrated $\left[{ }^{3} \mathrm{H}\right]$ strychnine-binding sites, mRNA, or protein of GlyR $\alpha 1$-subunit in rat or gerbil MNTB (Zarbin et al., 1981; Sato et al., 1995; Friauf et al., 1997; Korada and Schwartz, 1999; Sato et al., 2000; Piechotta et al., 2001). While the $\alpha 1$-containing heteromeric GlyRs mediate the majority of glycinergic synaptic transmission in the mature nervous system, evidence indicates functional $\alpha 2 / \beta$ and $\alpha 3 / \beta$ receptors in adult mice or rats (Lynch, 2009). In the MNTB and cochlear nucleus isolated from young adult rats, mRNAs of both $\alpha 2$ and $\alpha 3$ GlyR subunits were detected (Sato et al., 1995; Piechotta et al., 2001). Our immunohistochemistry and electrophysiology, however, did not detect these subunits in juvenile or adult rat MNTB slices suggesting that they may not significantly contribute to functional GlyRs expressed by MNTB neurons of this age.

The apposition of clusters of somatodendritic $\alpha 1 / \beta$ GlyRs to vGAT-positive nerve endings indicated the localization of the receptors at postsynaptic sites (Dumoulin et al., 1999; Korada and Schwartz, 1999). Smaller GlyR-immunoreactive clusters in MNTB neurons were frequently organized into rosette-like groups (Alvarez et al., 1997), previously identified in spinal motoneurons as corresponding to single presynaptic boutons (Walmsley et al., 1998). Our observations of multiple synaptic active zones within a larger apposition region of inhibitory nerve terminal on MNTB principal cells (Fig. $8 F$ ) are in agreement with this. In addition to somata and dendrites, the clusters of GlyRs also occupied proximal parts of postsynaptic axons of MNTB neurons suggesting that the receptors might play a role in modulation of postsynaptic action potential generation.
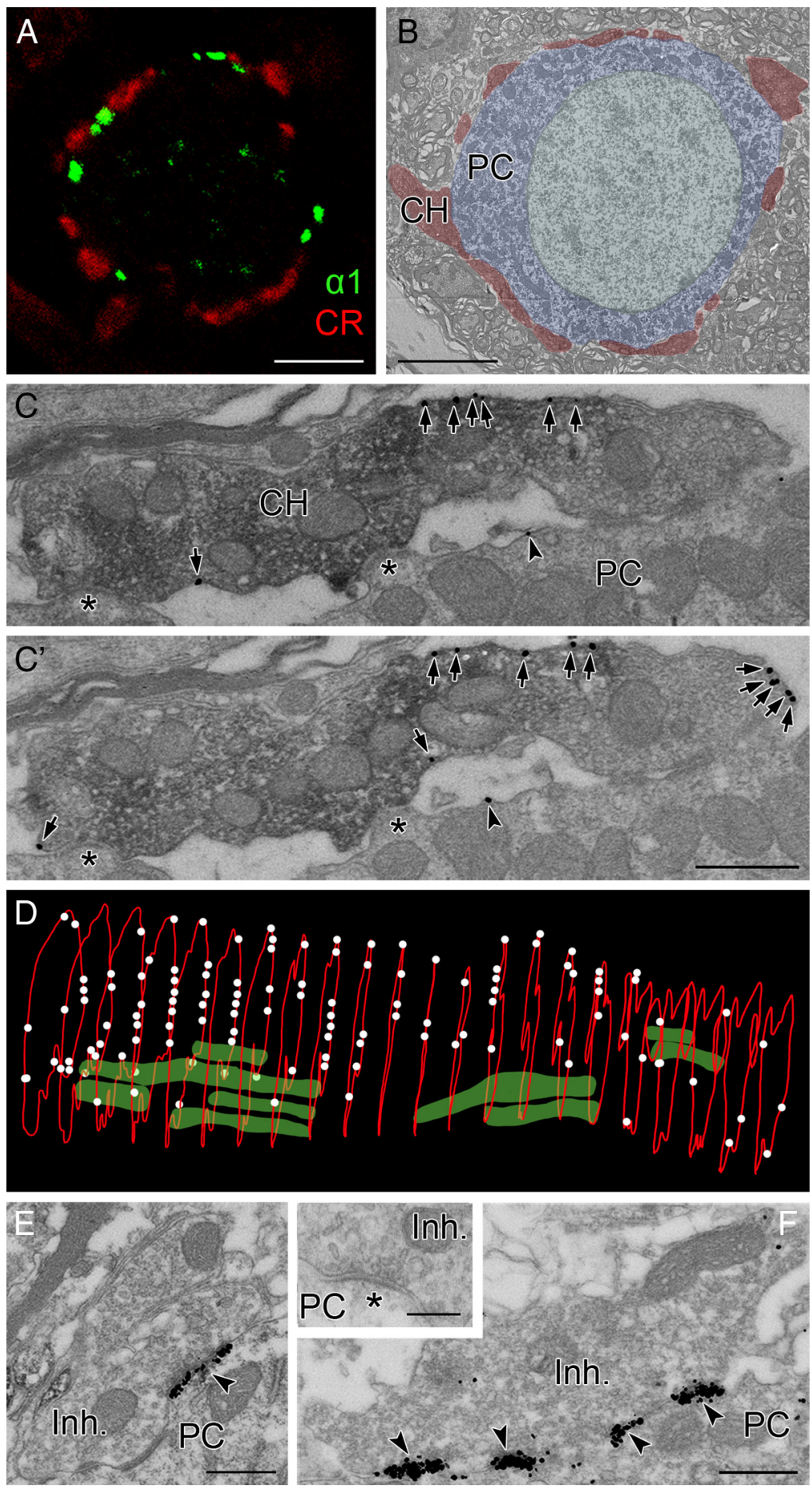

Figure 8. Diffuse versus clustered distribution of presynaptic versus postsynaptic GlyRs in MNTB. A, Double labeling of MNTB slice with antibodies raised against $\mathrm{CR}$ (red) and with antibodies recognizing an intracellular part of GlyR $\alpha 1$-subunit ( $\alpha 1$; green). Note the similar staining pattern to what has been observed with the antibodies raised against extracellular part of $\alpha 1$ (mAb2b). $B$, A single ultrathin section through a segment of the calyx (CH) surrounding the soma of the MNTB principal cell (PC). $C_{,} C^{\prime}$, Two consecutive ultrathin sections of a CH establishing asymmetric synaptic contacts (asterisks) with the soma of an MNTB PC. Calyceal processes were immunostained for VGluT1 (peroxidases reaction end product) and also showed immunoreactivity for $\alpha 1$ (immunogold particles; arrows) along the extrasynaptic plasma membrane. Moreover, GlyR subunits were occasionally observed on plasma membrane of PCs (arrowheads). D, 3D alignment of 22 serial ultrathin sections $(70 \mathrm{~nm}$ thick) of the same calyceal segment as in ( showing disperse membrane distribution of presynaptic GlyRs (white dots) relative to glutamate release sites (green). $\boldsymbol{E}$, Immunoreactivity for $\alpha 1$ (the same antibody as in A, C) was detected over the postsynaptic specialization (arrowhead) at symmetrical putative inhibitory synapses between vGluT1-negative terminals (Inh.) and somata of MNTB PCS. $\boldsymbol{F}$, Electron micrograph of MNTB slice double labeled with anti-gephyrin (gold particles) and anti-vGluT1 (peroxidase). Several neighboring clusters of densely packed gold particles (arrowheads) were typically observed at the membrane of principal cells under single vGluT1negative bouton (Inh.). Inset shows an example of symmetric synaptic contacts (asterisk) between vGluT1 negative terminal (Inh.) and a PC. Scale bars: $\boldsymbol{A}, \boldsymbol{B}, 5 \mu \mathrm{m} ; \boldsymbol{C}, \boldsymbol{E}, \boldsymbol{F}, 0.5 \mu \mathrm{m}$; inset in $\boldsymbol{F}, 0.25 \mu \mathrm{m}$. 

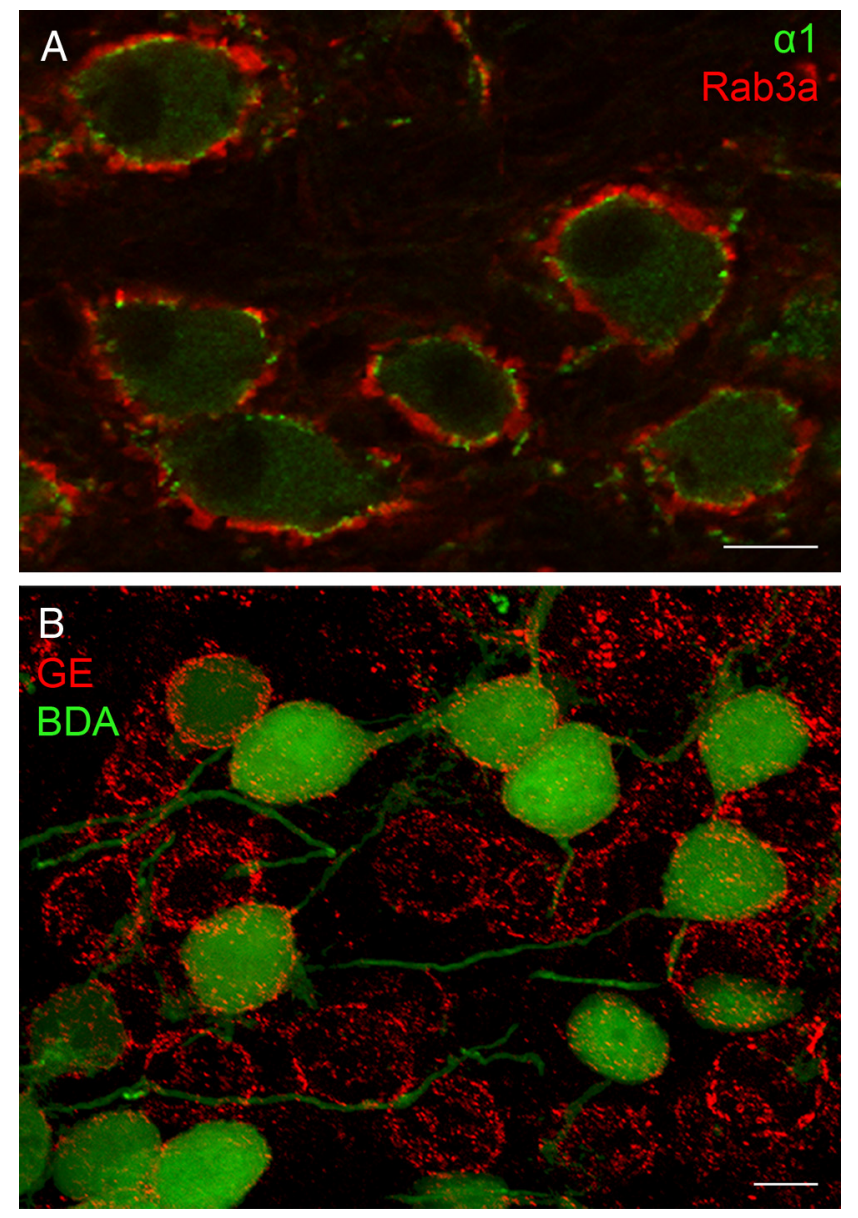

Figure 9. $\alpha 1 / \beta$ heteromeric GlyRs on somata of mature GBCs. $A$, A single confocal plane image of ventral cochlear nucleus double labeled with anti-Rab3a and anti- $\alpha 1$ (mAb2b). Note that $\alpha 1$-immunoreactive clusters (green) on GBCs do not colocalize with Rab3a-positive presynaptic nerve terminals (red). $B, A$ Z-series projection of eight images through $G B C$, retrogradely labeled with BDA (green), with numerous postsynaptic gephyrin-immunoreactive dots (red). Scale bars: $10 \mu \mathrm{m}$.

\section{Pharmacological properties of GlyRs in MNTB neurons}

Consistent with the subcellular distribution of GlyR subtypes suggested by our immunohistochemistry experiments, responses of presynaptic and postsynaptic GlyRs showed different sensitivities to subunit-specific drugs. We have found that calyceal but not somatodendritic GlyRs exhibited a high sensitivity to PTX confirming $\alpha$ homomeric composition of functional GlyRs expressed in the calyx of Held (Lynch et al., 1995; Legendre, 1997). Interestingly, $\alpha$ homomeric GlyRs were also suggested on glycinergic endings in the rat spinal sacral dorsal commissural nucleus (Jeong et al., 2003), supraoptic nucleus neurons, rod bipolar cells (Deleuze et al., 2005; Mørkve and Hartveit, 2009), and hippocampal mossy fibers (Kubota et al., 2010; but see Lee et al., 2009). This implies that homomeric receptors may represent a common form of GlyRs in mature nerve terminals, thereby constituting a presynaptic equivalent of adult postsynaptic $\alpha 1 / \beta$ heteromeric receptors. Further experiments will be needed to determine whether this subunit composition is found for presynaptic GlyRs identified in other brain regions (Kawa, 2003; Ye et al., 2004; Karnani et al., 2011).

Functional GlyRs on somatodendritic domains of MNTB principal cells and bushy cells could be classified as $\alpha / \beta$ heteromers based on their weak sensitivity to PTX and positive modulation by ICS 205.930. These observations complement similar findings previously made using PTX on type II neurons (putative bushy cells) of mice or guinea pigs ( $\mathrm{Wu}$ and Oertel, 1986; Harty and Manis, 1996). In rat, Kungel and Friauf (1997) discovered a high PTX-mediated inhibition of GlyRs in neonatal MNTB principal cells, which together with our data suggest a developmental transition from $\alpha 2$ homomers to $\alpha 1 / \beta$ heteromers (Lynch, 2004).

Presynaptic and postsynaptic functional GlyRs in MNTB commonly use the $\alpha 1$-subunit as they are highly sensitive to CTB but show weak sensitivity to PXN or CTZ (Pribilla et al., 1992; Rundström et al., 1994; Kungel and Friauf, 1997; Wang et al., 2007; Yang et al., 2007a). The evidence for presynaptic homomeric $\alpha 1$ is in line with the occurrence of $\sim 90 \mathrm{pS}$ events in singlechannel openings of calyceal GlyRs (Turecek and Trussell, 2002). In fact, the large unitary conductance (Takahashi et al., 1992; Bormann et al., 1993) and slower rates of both the deactivation and desensitization (Legendre et al., 2002; Mohammadi et al., 2003) distinguish the $\alpha 1$ homomeric GlyR from its $\beta$-subunitcontaining variant. Such properties could make homomeric receptors better suited then heteromeric receptors in responding to low concentrations of endogenous agonist (Muller et al., 2008). In accordance with this expectation, our previous experiments indicated activation of presynaptic GlyRs by glycine spillover (Turecek and Trussell, 2001).

The $\alpha 1 / \beta$ heteromeric GlyRs are characterized by fast activation/deactivation kinetics well suited to mediating fast postsynaptic inhibition (Singer and Berger, 2000; Legendre, 2001; Burzomato et al., 2004; Muller et al., 2008). Accordingly, both spontaneous and evoked IPSCs recorded from MNTB principal cells are indeed characterized by rapid rise times and decay phases (Lim et al., 2003; Awatramani et al., 2004; 2005b; Leao et al., 2004; Lu et al., 2008). A rapid time course enables IPSCs to follow glycinergic transmission elicited at frequencies up to $500 \mathrm{~Hz}$ (Awatramani et al., 2004). Moreover upon high-frequency stimulation, postsynaptic GlyRs did not fully respond to accumulated ambient glycine, as revealed by experimental increase of GlyR affinity in the presence of ICS 205.930 (Chesnoy-Marchais, 1996; Supplisson and Chesnoy-Marchais, 2000). We suggest that the reduced sensitivity of synaptic/extrasynaptic GlyRs to low concentrations of glycine minimizes tonic IPSCs and may be an adaptive feature of neurotransmission mediated by $\alpha 1 / \beta$ heteromeric receptors. Such a property of inhibitory receptors could be important at this auditory synapse because experimentally induced tonic inhibition was shown to interfere with precise processing of sound-evoked signals by auditory brainstem (Pecka et al., 2008).

In contrast to mIPSCs or tonic and phasic currents during high-frequency stimuli, low-frequency IPSCs were not potentiated by ICS 205.930. A similar observation was previously made using zinc and suggests high peak occupancy of GlyRs by synaptic glycine (Laube, 2002). While synaptic GlyRs are not supposed to be saturated by single quanta (Suwa et al., 2001; Rigo et al., 2003; Beato, 2008), their occupancy could be increased by lateral diffusion of agonist between postsynaptic sites, thus enhancing the amplitude of the compound IPSC (Faber and Korn, 1988). Consistent with this idea, we observed the rise time of IPSCs to be moderately slower than that previously found for mIPSCs (Lim et al., 2003; Lu et al., 2008), although the time course of exocytosis could contribute to this slowing as well. This view also suggests that a sensitivity of GlyRs to glycine spillover differs depending on the ligation state (Burzomato et al., 2004). Increase of affinity of GlyRs by ICS 205.930 would then elevate amplitudes of tonic IPSCs and subsequently also high-frequency IPSCs. While addi- 
tional experiments would be needed to confirm this, we suggest that responses of postsynaptic GlyRs in MNTB tightly follow the timing of transmitter release, demonstrating a strikingly phasic character. This contrasts with presumably slow activation of presynaptic GlyRs by glycine spillover (Turecek and Trussell, 2001; Kopp-Scheinpflug et al., 2008). The calyx of Held synapse therefore illustrates that the absence vs presence of the $\beta$-subunit in a receptor oligomer determines the "tonic" vs "phasic" character of the glycinergic transmission in the CNS (Betz and Laube, 2006).

\section{References}

Alvarez FJ, Dewey DE, Harrington DA, Fyffe RE (1997) Cell-type specific organization of glycine receptor clusters in the mammalian spinal cord. J Comp Neurol 379:150-170. CrossRef Medline

Awatramani GB, Turecek R, Trussell LO (2004) Inhibitory control at a synaptic relay. J Neurosci 24:2643-2647. CrossRef Medline

Awatramani GB, Price GD, Trussell LO (2005a) Modulation of transmitter release by presynaptic resting potential and background calcium levels. Neuron 48:109-121. CrossRef Medline

Awatramani GB, Turecek R, Trussell LO (2005b) Staggered development of GABAergic and glycinergic transmission in the MNTB. J Neurophysiol 93:819-828. Medline

Banks MI, Smith PH (1992) Intracellular recordings from neurobiotinlabeled cells in brain slices of the rat medial nucleus of the trapezoid body. J Neurosci 12:2819-2837. Medline

Bausen M, Weltzien F, Betz H, O'Sullivan GA (2010) Regulation of postsynaptic gephyrin cluster size by protein phosphatase 1. Mol Cell Neurosci 44:201-209. CrossRef Medline

Beato M (2008) The time course of transmitter at glycinergic synapses onto motoneurons. J Neurosci 28:7412-7425. CrossRef Medline

Betz H, Laube B (2006) Glycine receptors: recent insights into their structural organization and functional diversity. J Neurochem 97: 1600-1610. CrossRef Medline

Billups B (2005) Colocalization of vesicular glutamate transporters in the rat superior olivary complex. Neurosci Lett 382:66-70. CrossRef Medline

Bormann J, Rundström N, Betz H, Langosch D (1993) Residues within transmembrane segment $\mathrm{M} 2$ determine chloride conductance of glycine receptor homo- and hetero-oligomers. EMBO J 12:3729-3737. Medline

Borst JG, Soria van Hoeve J (2012) The calyx of held synapse: from model synapse to auditory relay. Annu Rev Physiol 74:199-224. CrossRef Medline

Burzomato V, Beato M, Groot-Kormelink PJ, Colquhoun D, Sivilotti LG (2004) Single-channel behavior of heteromeric alphalbeta glycine receptors: an attempt to detect a conformational change before the channel opens. J Neurosci 24:10924-10940. CrossRef Medline

Charrier C, Machado P, Tweedie-Cullen RY, Rutishauser D, Mansuy IM, Triller A (2010) A crosstalk between betal and beta3 integrins controls glycine receptor and gephyrin trafficking at synapses. Nat Neurosci 13: 1388-1395. CrossRef Medline

Chesnoy-Marchais D (1996) Potentiation of chloride responses to glycine by three 5 -HT3 antagonists in rat spinal neurones. Br J Pharmacol 118: 2115-2125. CrossRef Medline

Deleuze C, Runquist M, Orcel H, Rabié A, Dayanithi G, Alonso G, Hussy N (2005) Structural difference between heteromeric somatic and homomeric axonal glycine receptors in the hypothalamo-neurohypophysial system. Neuroscience 135:475-483. CrossRef Medline

Dumoulin A, Rostaing P, Bedet C, Lévi S, Isambert MF, Henry JP, Triller A, Gasnier B (1999) Presence of the vesicular inhibitory amino acid transporter in GABAergic and glycinergic synaptic terminal boutons. J Cell Sci 112:811-823. Medline

Dumoulin A, Triller A, Kneussel M (2009) Cellular transport and membrane dynamics of the glycine receptor. Front Mol Neurosci 2:28. Medline

Faber DS, Korn H (1988) Synergism at central synapses due to lateral diffusion of transmitter. Proc Natl Acad Sci U S A 85:8708-8712. CrossRef Medline

Felmy F, Schneggenburger R (2004) Developmental expression of the $\mathrm{Ca} 2+$-binding proteins calretinin and parvalbumin at the calyx of held of rats and mice. Eur J Neurosci 20:1473-1482. CrossRef Medline

Feng G, Tintrup H, Kirsch J, Nichol MC, Kuhse J, Betz H, Sanes JR (1998) Dual requirement for gephyrin in glycine receptor clustering and molybdoenzyme activity. Science 282:1321-1324. CrossRef Medline
Flint AC, Liu X, Kriegstein AR (1998) Nonsynaptic glycine receptor activation during early neocortical development. Neuron 20:43-53. CrossRef Medline

Forsythe ID (1994) Direct patch recording from identified presynaptic terminals mediating glutamatergic EPSCs in the rat CNS, in vitro. J Physiol 479:381-387. Medline

Friauf E (1993) Transient appearance of calbindin-D28k-positive neurons in the superior olivary complex of developing rats. J Comp Neurol 334: 59-74. CrossRef Medline

Friauf E, Hammerschmidt B, Kirsch J (1997) Development of adult-type inhibitory glycine receptors in the central auditory system of rats. J Comp Neurol 385:117-134. CrossRef Medline

Fritschy JM, Harvey RJ, Schwarz G (2008) Gephyrin: where do we stand, where do we go? Trends Neurosci 31:257-264. CrossRef Medline

Grothe B, Pecka M, McAlpine D (2010) Mechanisms of sound localization in mammals. Physiol Rev 90:983-1012. CrossRef Medline

Grudzinska J, Schemm R, Haeger S, Nicke A, Schmalzing G, Betz H, Laube B (2005) The beta subunit determines the ligand binding properties of synaptic glycine receptors. Neuron 45:727-739. CrossRef Medline

Harty TP, Manis PB (1996) Glycine-evoked currents in acutely dissociated neurons of the guinea pig ventral cochlear nucleus. J Neurophysiol 75: 2300-2311. Medline

Hori T, Takahashi T (2009) Mechanisms underlying short-term modulation of transmitter release by presynaptic depolarization. J Physiol 587: 2987-3000. CrossRef Medline

Jeong HJ, Jang IS, Moorhouse AJ, Akaike N (2003) Activation of presynaptic glycine receptors facilitates glycine release from presynaptic terminals synapsing onto rat spinal sacral dorsal commissural nucleus neurons. J Physiol 550:373-383. CrossRef Medline

Kandler K, Gillespie DC (2005) Developmental refinement of inhibitory sound-localization circuits. Trends Neurosci 28:290-296. CrossRef Medline

Karnani MM, Venner A, Jensen LT, Fugger L, Burdakov D (2011) Direct and indirect control of orexin/hypocretin neurons by glycine receptors. J Physiol 589:639-651. CrossRef Medline

Kawa K (2003) Glycine facilitates transmitter release at developing synapses: a patch clamp study from Purkinje neurons of the newborn rat. Brain Res Dev Brain Res 144:57-71. Medline

Kirsch J, Langosch D, Prior P, Littauer UZ, Schmitt B, Betz H (1991) The 93-kDa glycine receptor-associated protein binds to tubulin. J Biol Chem 266:22242-22245. Medline

Kneussel M, Betz H (2000a) Clustering of inhibitory neurotransmitter receptors at developing postsynaptic sites: the membrane activation model. Trends Neurosci 23:429-435. CrossRef Medline

Kneussel M, Betz H (2000b) Receptors, gephyrin and gephyrin-associated proteins: novel insights into the assembly of inhibitory postsynaptic membrane specializations. J Physiol 525:1-9.

Kneussel M, Loebrich S (2007) Trafficking and synaptic anchoring of ionotropic inhibitory neurotransmitter receptors. Biol Cell 99:297-309. CrossRef Medline

Kopp-Scheinpflug C, Dehmel S, Tolnai S, Dietz B, Milenkovic I, Rübsamen R (2008) Glycine-mediated changes of onset reliability at a mammalian central synapse. Neuroscience 157:432-445. CrossRef Medline

Kopp-Scheinpflug C, Steinert JR, Forsythe ID (2011) Modulation and control of synaptic transmission across the MNTB. Hear Res 279:22-31. CrossRef Medline

Korada S, Schwartz IR (1999) Development of GABA, glycine, and their receptors in the auditory brainstem of gerbil: a light and electron microscopic study. J Comp Neurol 409:664-681. CrossRef Medline

Kubota H, Alle H, Betz H, Geiger JR (2010) Presynaptic glycine receptors on hippocampal mossy fibers. Biochem Biophys Res Commun 393: 587-591. CrossRef Medline

Kulik A, Vida I, Luján R, Haas CA, López-Bendito G, Shigemoto R, Frotscher M (2003) Subcellular localization of metabotropic GABA(B) receptor subunits $\mathrm{GABA}(\mathrm{B} 1 \mathrm{a} / \mathrm{b})$ and $\mathrm{GABA}(\mathrm{B} 2)$ in the rat hippocampus. J Neurosci 23:11026-11035. Medline

Kungel M, Friauf E (1997) Physiology and pharmacology of native glycine receptors in developing rat auditory brainstem neurons. Brain Res Dev Brain Res 102:157-165. Medline

Laube B (2002) Potentiation of inhibitory glycinergic neurotransmission by $\mathrm{Zn} 2+$ : a synergistic interplay between presynaptic $\mathrm{P} 2 \mathrm{X} 2$ and postsynaptic glycine receptors. Eur J Neurosci 16:1025-1036. CrossRef Medline 
Laube B, Maksay G, Schemm R, Betz H (2002) Modulation of glycine receptor function: a novel approach for therapeutic intervention at inhibitory synapses? Trends Pharmacol Sci 23:519-527. CrossRef Medline

Leao RN, Oleskevich S, Sun H, Bautista M, Fyffe RE, Walmsley B (2004) Differences in glycinergic mIPSCs in the auditory brain stem of normal and congenitally deaf neonatal mice. J Neurophysiol 91:1006-1012. Medline

Lee EA, Cho JH, Choi IS, Nakamura M, Park HM, Lee JJ, Lee MG, Choi BJ, Jang IS (2009) Presynaptic glycine receptors facilitate spontaneous glutamate release onto hilar neurons in the rat hippocampus. J Neurochem 109:275-286. CrossRef Medline

Legendre P (1997) Pharmacological evidence for two types of postsynaptic glycinergic receptors on the Mauthner cell of 52-h-old zebrafish larvae. J Neurophysiol 77:2400-2415. Medline

Legendre P (2001) The glycinergic inhibitory synapse. Cell Mol Life Sci 58: 760-793. CrossRef Medline

Legendre P, Muller E, Badiu CI, Meier J, Vannier C, Triller A (2002) Desensitization of homomeric alphal glycine receptor increases with receptor density. Mol Pharmacol 62:817-827. CrossRef Medline

Legendre P, Förstera B, Jüttner R, Meier JC (2009) Glycine receptors caught between genome and proteome-functional implications of RNA editing and splicing. Front Mol Neurosci 2:23. Medline

Lim R, Alvarez FJ, Walmsley B (1999) Quantal size is correlated with receptor cluster area at glycinergic synapses in the rat brainstem. J Physiol 516:505-512. CrossRef Medline

Lim R, Alvarez FJ, Walmsley B (2000) GABA mediates presynaptic inhibition at glycinergic synapses in a rat auditory brainstem nucleus. J Physiol 525:447-459. CrossRef Medline

Lim R, Oleskevich S, Few AP, Leao RN, Walmsley B (2003) Glycinergic mIPSCs in mouse and rat brainstem auditory nuclei: modulation by ruthenium red and the role of calcium stores. J Physiol 546:691-699. CrossRef Medline

Lohmann C, Friauf E (1996) Distribution of the calcium-binding proteins parvalbumin and calretinin in the auditory brainstem of adult and developing rats. J Comp Neurol 367:90-109. CrossRef Medline

Lu T, Rubio ME, Trussell LO (2008) Glycinergic transmission shaped by the corelease of GABA in a mammalian auditory synapse. Neuron 57:524535. CrossRef Medline

Lynch JW (2004) Molecular structure and function of the glycine receptor chloride channel. Physiol Rev 84:1051-1095. CrossRef Medline

Lynch JW (2009) Native glycine receptor subtypes and their physiological roles. Neuropharmacology 56:303-309. CrossRef Medline

Lynch JW, Rajendra S, Barry PH, Schofield PR (1995) Mutations affecting the glycine receptor agonist transduction mechanism convert the competitive antagonist, picrotoxin, into an allosteric potentiator. J Biol Chem 270:13799-13806. CrossRef Medline

Maas C, Belgardt D, Lee HK, Heisler FF, Lappe-Siefke C, Magiera MM, van Dijk J, Hausrat TJ, Janke C, Kneussel M (2009) Synaptic activation modifies microtubules underlying transport of postsynaptic cargo. Proc Natl Acad Sci U S A 106:8731-8736. CrossRef Medline

Mohammadi B, Krampfl K, Cetinkaya C, Moschref H, Grosskreutz J, Dengler R, Bufler J (2003) Kinetic analysis of recombinant mammalian alpha(1) and alpha(1)beta glycine receptor channels. Eur Biophys J 32:529-536. CrossRef Medline

Mørkve SH, Hartveit E (2009) Properties of glycine receptors underlying synaptic currents in presynaptic axon terminals of rod bipolar cells in the rat retina. J Physiol 587:3813-3830. CrossRef Medline

Moss SJ, Smart TG (2001) Constructing inhibitory synapses. Nat Rev Neurosci 2:240-250. CrossRef Medline

Muller E, Le-Corronc H, Legendre P (2008) Extrasynaptic and postsynaptic receptors in glycinergic and GABAergic neurotransmission: a division of labor? Front Mol Neurosci 1:3. Medline

Oertel D (1999) The role of timing in the brain stem auditory nuclei of vertebrates. Annu Rev Physiol 61:497-519. CrossRef Medline

Pecka M, Brand A, Behrend O, Grothe B (2008) Interaural time difference processing in the mammalian medial superior olive: the role of glycinergic inhibition. J Neurosci 28:6914-6925. CrossRef Medline

Pfeiffer F, Simler R, Grenningloh G, Betz H (1984) Monoclonal antibodies and peptide mapping reveal structural similarities between the subunits of the glycine receptor of rat spinal cord. Proc Natl Acad Sci U S A 81: 7224-7227. CrossRef Medline

Piechotta K, Weth F, Harvey RJ, Friauf E (2001) Localization of rat glycine receptor alpha1 and alpha2 subunit transcripts in the developing auditory brainstem. J Comp Neurol 438:336-352. CrossRef Medline

Pribilla I, Takagi T, Langosch D, Bormann J, Betz H (1992) The atypical M2 segment of the beta subunit confers picrotoxinin resistance to inhibitory glycine receptor channels. EMBO J 11:4305-4311. Medline

Price GD, Trussell LO (2006) Estimate of the chloride concentration in a central glutamatergic terminal: a gramicidin perforated-patch study on the calyx of Held. J Neurosci 26:11432-11436. CrossRef Medline

Rigo JM, Badiu CI, Legendre P (2003) Heterogeneity of postsynaptic receptor occupancy fluctuations among glycinergic inhibitory synapses in the zebrafish hindbrain. J Physiol 553:819-832. CrossRef Medline

Rundström N, Schmieden V, Betz H, Bormann J, Langosch D (1994) Cyanotriphenylborate: subtype-specific blocker of glycine receptor chloride channels. Proc Natl Acad Sci U S A 91:8950-8954. CrossRef Medline

Sato K, Kuriyama H, Altschuler RA (1995) Expression of glycine receptor subunits in the cochlear nucleus and superior olivary complex using nonradioactive in-situ hybridization. Hear Res 91:7-18. CrossRef Medline

Sato K, Shiraishi S, Nakagawa H, Kuriyama H, Altschuler RA (2000) Diversity and plasticity in amino acid receptor subunits in the rat auditory brain stem. Hear Res 147:137-144. CrossRef Medline

Schmieden V, Grenningloh G, Schofield PR, Betz H (1989) Functional expression in Xenopus oocytes of the strychnine binding $48 \mathrm{kd}$ subunit of the glycine receptor. EMBO J 8:695-700. Medline

Schneggenburger R, Forsythe ID (2006) The calyx of Held. Cell Tissue Res 326:311-337. CrossRef Medline

Schofield PR, Shivers BD, Seeburg PH (1990) The role of receptor subtype diversity in the CNS. Trends Neurosci 13:8-11. CrossRef Medline

Singer JH, Berger AJ (2000) Development of inhibitory synaptic transmission to motoneurons. Brain Res Bull 53:553-560. CrossRef Medline

Smith PH, Joris PX, Yin TC (1998) Anatomy and physiology of principal cells of the medial nucleus of the trapezoid body (MNTB) of the cat. J Neurophysiol 79:3127-3142. Medline

Specht CG, Triller A (2008) The dynamics of synaptic scaffolds. Bioessays 30:1062-1074. CrossRef Medline

Supplisson S, Chesnoy-Marchais D (2000) Glycine receptor beta subunits play a critical role in potentiation of glycine responses by ICS-205,930. Mol Pharmacol 58:763-770. Medline

Suwa H, Saint-Amant L, Triller A, Drapeau P, Legendre P (2001) Highaffinity zinc potentiation of inhibitory postsynaptic glycinergic currents in the zebrafish hindbrain. J Neurophysiol 85:912-925. Medline

Takahashi T, Momiyama A, Hirai K, Hishinuma F, Akagi H (1992) Functional correlation of fetal and adult forms of glycine receptors with developmental changes in inhibitory synaptic receptor channels. Neuron 9:1155-1161. CrossRef Medline

Telgkamp P, Raman IM (2002) Depression of inhibitory synaptic transmission between Purkinje cells and neurons of the cerebellar nuclei. J Neurosci 22:8447-8457. Medline

Triller A, Cluzeaud F, Pfeiffer F, Betz H, Korn H (1985) Distribution of glycine receptors at central synapses: an immunoelectron microscopy study. J Cell Biol 101:683-688. CrossRef Medline

Turecek R, Trussell LO (2001) Presynaptic glycine receptors enhance transmitter release at a mammalian central synapse. Nature 411:587590. CrossRef Medline

Turecek R, Trussell LO (2002) Reciprocal developmental regulation of presynaptic ionotropic receptors. Proc Natl Acad Sci U S A 99:1388413889. CrossRef Medline

Tyagarajan SK, Ghosh H, Yévenes GE, Nikonenko I, Ebeling C, Schwerdel C, Sidler C, Zeilhofer HU, Gerrits B, Muller D, Fritschy JM (2011) Regulation of GABAergic synapse formation and plasticity by GSK3beta-dependent phosphorylation of gephyrin. Proc Natl Acad Sci U S A 108:379-384. CrossRef Medline

Veenman CL, Reiner A, Honig MG (1992) Biotinylated dextran amine as an anterograde tracer for single- and double-labeling studies. J Neurosci Methods 41:239-254. CrossRef Medline

von Gersdorff H, Borst JG (2002) Short-term plasticity at the calyx of held. Nat Rev Neurosci 3:53-64. CrossRef Medline

Walmsley B, Alvarez FJ, Fyffe RE (1998) Diversity of structure and function at mammalian central synapses. Trends Neurosci 21:81-88. CrossRef Medline

Wang DS, Mangin JM, Moonen G, Rigo JM, Legendre P (2006) Mechanisms for picrotoxin block of alpha2 homomeric glycine receptors. J Biol Chem 281:3841-3855. CrossRef Medline 
Wang DS, Buckinx R, Lecorronc H, Mangin JM, Rigo JM, Legendre P (2007) Mechanisms for picrotoxinin and picrotin blocks of alpha2 homomeric glycine receptors. J Biol Chem 282:16016-16035. CrossRef Medline

Webb TI, Lynch JW (2007) Molecular pharmacology of the glycine receptor chloride channel. Curr Pharm Des 13:2350-2367. CrossRef Medline

Wojcik SM, Katsurabayashi S, Guillemin I, Friauf E, Rosenmund C, Brose N, Rhee JS (2006) A shared vesicular carrier allows synaptic corelease of GABA and glycine. Neuron 50:575-587. CrossRef Medline

Wu SH, Kelly JB (1995) Inhibition in the superior olivary complex: pharmacological evidence from mouse brain slice. J Neurophysiol 73: 256-269. Medline

Wu SH, Oertel D (1986) Inhibitory circuitry in the ventral cochlear nucleus is probably mediated by glycine. J Neurosci 6:2691-2706. Medline

Yang Z, Cromer BA, Harvey RJ, Parker MW, Lynch JW (2007a) A proposed structural basis for picrotoxinin and picrotin binding in the glycine receptor pore. J Neurochem 103:580-589. CrossRef Medline

Yang Z, Ney A, Cromer BA, Ng HL, Parker MW, Lynch JW (2007b) Tro- pisetron modulation of the glycine receptor: femtomolar potentiation and a molecular determinant of inhibition. J Neurochem 100:758-769. CrossRef Medline

Ye JH, Wang F, Krnjevic K, Wang W, Xiong ZG, Zhang J (2004) Presynaptic glycine receptors on GABAergic terminals facilitate discharge of dopaminergic neurons in ventral tegmental area. J Neurosci 24: 8961-8974. CrossRef Medline

Zarbin MA, Wamsley JK, Kuhar MJ (1981) Glycine receptor: light microscopic autoradiographic localization with $[3 \mathrm{H}]$ strychnine. J Neurosci 1:532-547. Medline

Zhang XB, Sun GC, Liu LY, Yu F, Xu TL (2008) Alpha2 subunit specificity of cyclothiazide inhibition on glycine receptors. Mol Pharmacol 73: 1195-1202. CrossRef Medline

Zhorov BS, Bregestovski PD (2000) Chloride channels of glycine and GABA receptors with blockers: Monte Carlo minimization and structureactivity relationships. Biophys J 78:1786-1803. CrossRef Medline 